\title{
Granite Exploration by using Electrical Resistivity Imaging (ERI): A Case Study in Johor
}

\author{
M. S. I. Zaini ${ }^{1}$, M. F. Ishak ${ }^{1,4^{*}}$, M. F. Zolkepli ${ }^{1}$, M. S. Wahap ${ }^{1}$, J. I. Jaafar Sidek ${ }^{1}$, \\ A. Mohd Yasin', M. N. Zolkepli', M. H. Mohmad Sidik², K. Z. Mohd Arof', \\ Z. Abu Talib ${ }^{5}$
}

${ }^{1}$ Faculty of Civil Engineering Technology, Universiti Malaysia Pahang, Lebuhraya Tun Razak, 26300 Kuantan, Pahang, MALAYSIA

${ }^{2}$ Fakulti Keusahawanan dan Perniagaan, Universiti Malaysia Kelantan, Taman Bendahara, 16100 Pengkalan Chepa, Pahang, MALAYSIA

${ }^{3}$ Razak Faculty of Technology and Informatics,

Universiti Teknologi Malaysia Kuala Lumpur, Jalan Sultan Yahya Petra, 54100 Kuala Lumpur, MALAYSIA

${ }^{4}$ Earth Resources and Sustainability (ERAS),

Universiti Malaysia Pahang, Lebuhraya Tun Razak, 26300 Gambang, Kuantan, Pahang, MALAYSIA

${ }^{5}$ Faculty of Civil Engineering and Built Environment,

Universiti Tun Hussein Onn Malaysia, 86400 Parit Raja, Johor, MALAYSIA

*Corresponding Author

DOI: https://doi.org/10.30880/ijie.2020.12.08.032

Received 12 May 2020; Accepted 20 August 2020; Available online 15 September 2020

\begin{abstract}
Electrical Resistivity Imaging (ERI) is a tool used in near surface geophysical surveys by flowing an electric current through electrodes that were injected into the ground. The usage of electrical resistivity imaging (ERI) method dominated by geophysicist has increased tremendously in geotechnical engineering application owing to the efficiency and effectiveness of the method in term of time, cost and also data coverage. The survey performed with respect to the particular reference to ERI in determining the granite rock underneath the ground. There were seven (7) lines of ERI performed at the study area by using ABEM Terrameter LS 2 set of equipment based on Schlumberger protocol. Six (6) boreholes were also drilled to obtain engineering properties of rock at the study area. In order to develop the relationship between resistivity and engineering properties, a comparison between borehole field test result and the resistivity value were made. Results from the ERI indicated the presence of zones with high resistivity values identified as overburden soil, fractured granite and solid granite. The findings of this study also showed that the electrical resistivity imaging coupled with borehole drillings were applicable tools for the determination of the granite rock underneath the ground via subsurface profiles and such as depth of overburden soil and engineering properties of soil. In conclusion, ERI is a method that does not disturb the structure or the function of the soil which successfully became the best method in exploring the granite rock.
\end{abstract}

Keywords: Electrical resistivity imaging, geophysical survey, geophysicist, granite rock, borehole, Schlumberger protocol, engineering properties of soil 


\section{Introduction}

In geotechnical engineering, the geophysical method which was originated from physical sciences is rapidly increase in demand. Geophysics is a term that describes the study of earth based on physics properties such as electrical resistivity, velocity, density, magnetic field, magnetic susceptibility and many more. In real world situations, applications of physics theory are provided with the venue from the cross-disciplinary field of geophysics. Starting with the concepts, performance of mathematical derivation and revealing the application of the mathematical result to the physics world is a role of geophysics that met the needs of the populations [1]. The acquisition geometry for 2D electrical resistivity imaging data can be emphasized for the current development [2]. By using wide spacing between the electrodes which can result to the depth of explorations roughly of 60 meters in the central parts of some measured sections [3]. Geophysical methods play an important role in finding the hidden subsurface of a soil accurately and adequately without bore holing or drilling [4]. Last decades, ERI method has broadly being used in soil characterization but experienced several arguments related to its interpretations and results [5].

As discussed by [6] and [7]-[9], Geophysical investigation offers a faster, cheaper and has the ability to cover greater areas more thoroughly as stated by [10]; [11] by getting credible and detailed information about the subsurface [12]. Various researchers from all over the world especially in geophysics and geotechnical field have exposed that the integration of geotechnical data and geophysical survey can provide a useful data and interpretation for sub-surface profile characterization [13]-[16]. However, the standard performance electrical resistivity method always dependable on the physical limitations such as resolution, penetration and signal to-noise ratio [17].

In selecting or choosing the suitable geophysical method to be used, there are several criteria that can be used as a guideline. First, the objectives of the work to be conducted. It is very important to know whether the geophysical method are used for water, rock, soil, cavity, tombs and so on. Second, what is the physical properties to be measured based on the work objectives to be conducted. Different physic properties need different method to be conducted. Third, the decision on which method or setting are the most suitable to the work objectives. Fourth, is the site noisy and lastly are there any previous data or record published related to the work that will be conducted [18].

\subsection{Geological Setting}

The survey area is in Batu Pahat at approximate latitude of $1^{\circ} 48^{\prime} 10.6^{\prime \prime} \mathrm{N}$ and longitude of $102^{\circ} 55^{\prime} 36.6^{\prime \prime E}$. Area of the survey is located within acidic intrusive rock area on the southern part of Eastern Belt of Peninsular Malaysia (Fig. 1). The bedrock of survey area is believed to be Triassic Main Range granite, S-type granite particularly Chembong pluton. Chembong pluton was described as homogeneous, fine to medium grained equigranular granites with few Kfeldspar phenocrysts and predominantly coarse-grained sparsely megacrystic biotite granite [20].

The survey area is in the secondary forest which the area of is being overlain by light yellow silty SAND weathered soil. The ground elevation for the survey area is ranging from $160-779 \mathrm{~m}$. There are some granite outcrops were observed in boulder and block sizes at stream and cascades within the survey area. In general, the present of boulders and soil formation exhibit the occurrence of weathering process that breakdown the granitic rocks into weathered overburden soil.

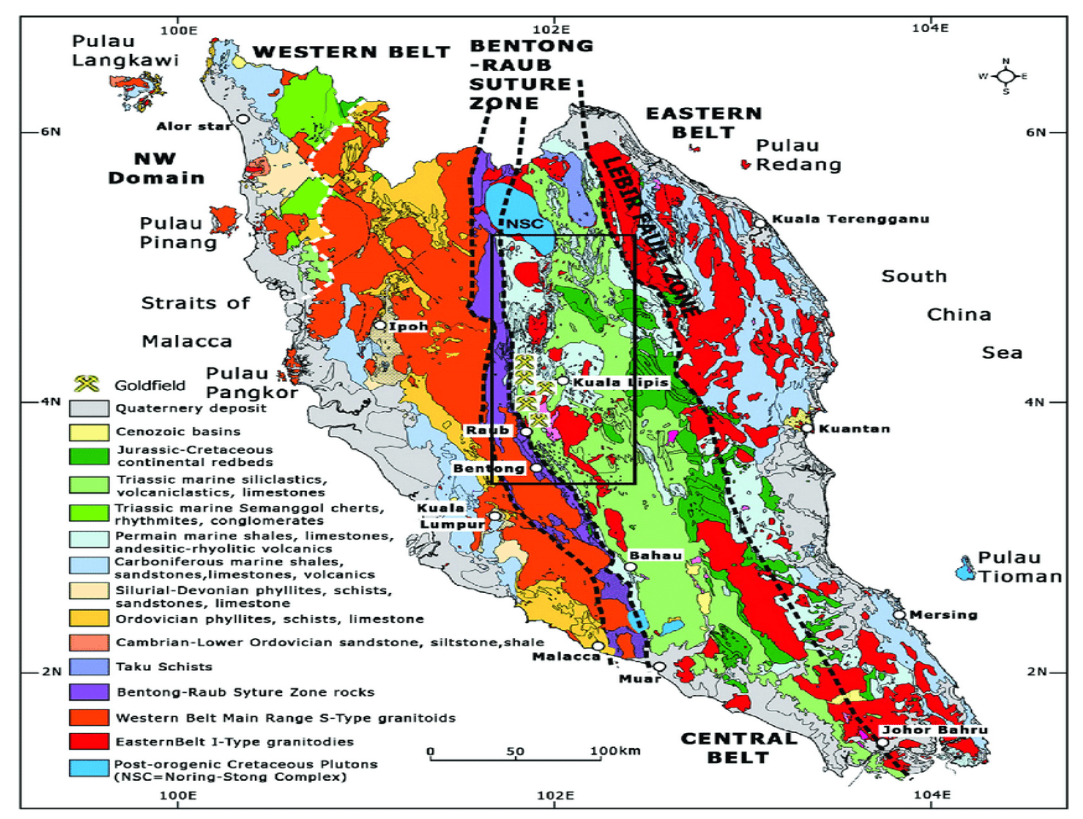

Fig. 1 - Map of peninsular Malaysia showing the three belts and lithologies. Modified from [21] 


\section{Methodology}

Based on this study, five (5) borehole drillings were carried out precedent to the ERI survey, one (1) borehole drilling were carried out near resistivity survey line 5 and two (2) resistivity survey lines were carried out without precedent to the borehole drillings. Hence, the alignment of five (5) resistivity lines was proposed based on the location of the boreholes.

Preceding to outlining the methodology used, it would be beneficial to introduce the basic concept of the electrical resistivity. The electrical resistivity method relies on determining the resistance underneath the earth's surface [19]. The resistance measurement is basically made by allowing the current (I) to flow through the subsurface through the electrode that was injected into the ground. In this case, the resistivity of the electric is calculated based on Ohm's Law formula:

$$
R=\rho\left(\frac{L}{A}\right) \Omega
$$

where $\rho=$ Electrical Resistivity; $L=$ Length in meters (m); and $A=$ Area in square meters $\left(\mathrm{m}^{2}\right)$.

When current (I) is applied into the ground through electrodes and the potential difference between the two ends of the ground is measured using voltmeter in volts $(\mathrm{V})$, the resistance $(\mathrm{R})$ of the ground is equal to the ratio of the voltage applied to current $(\mathrm{V} / \mathrm{I})$. The resistance $(\mathrm{R})$ of a conductor is inversely proportional to the cross-section area $(A)$ and is directly proportional to length (L) [19]. The electrical resistivity survey was carried out using Abem Terrameter LS 2 for the detection of granitic bedrock at the site. The survey system has been tested and calibrated prior to the commencement of the data acquisition to optimize system performance and attain the prescribed survey accuracies. RMS error were evaluated to validate the data.

\subsection{Borehole Drilling}

The methods for advancing the boreholes were by rotary wash boring, continuous sampling, rotary drilling or a combination of these methods at different locations. Casing with tungsten carbide shoe is used for drilling in overburden soil. Soil types were determined from colour of returned water and washed drill cuttings. When sound bedrock or boulder is encountered, rock drilling method is adopted. Six (6) boreholes, namely BH1, BH2, BH3, BH4, BH5 and BH6 located near the resistivity survey line as shown in Fig. 2 and Fig. 3 (presented by red dot) were chosen to be compared to the resistivity analysis in determining the exact location of the granite rock.

\subsection{D Electrical resistivity Imaging (ERI) Method}

Resistivity method is an electrical geophysical imaging method to measure subsurface apparent resistance distribution by injecting DC current into the ground using 2 current electrodes (C1 and $\mathrm{C} 2)$. A potential difference is measured using 2 potential electrodes (P1 and P2). Electrical imaging system is mainly carried out with a multielectrode resistivity meter system as shown in Fig. 4.

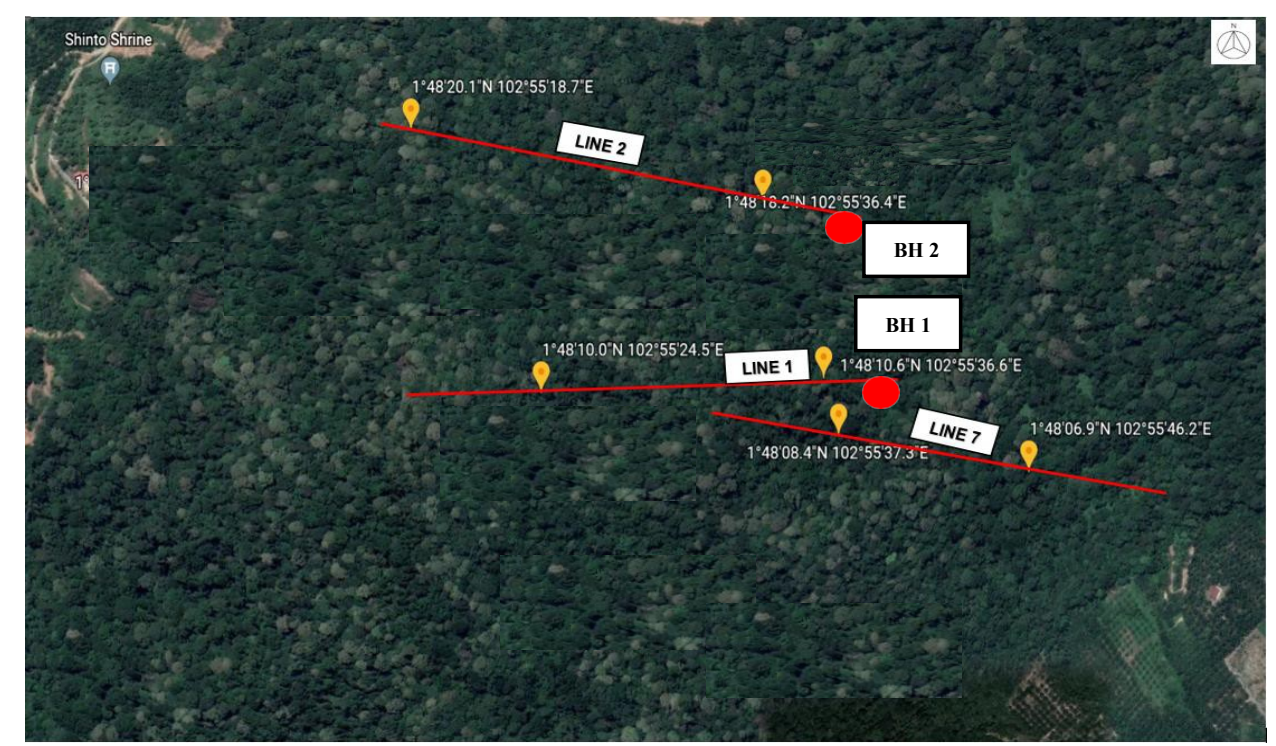

Fig. 2 - Borehole location (BH1 \& BH2) 


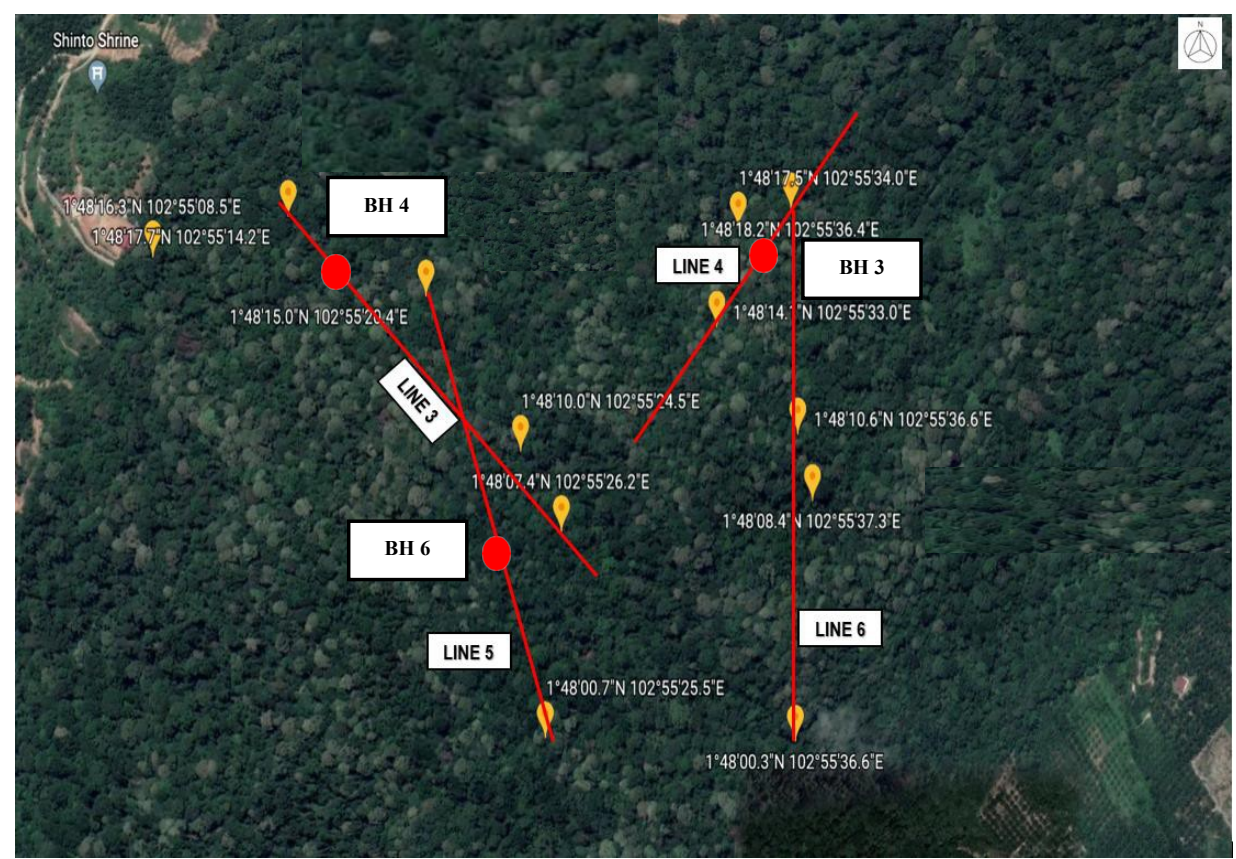

Fig. 3 - Borehole location (BH3, BH4 \& BH6)

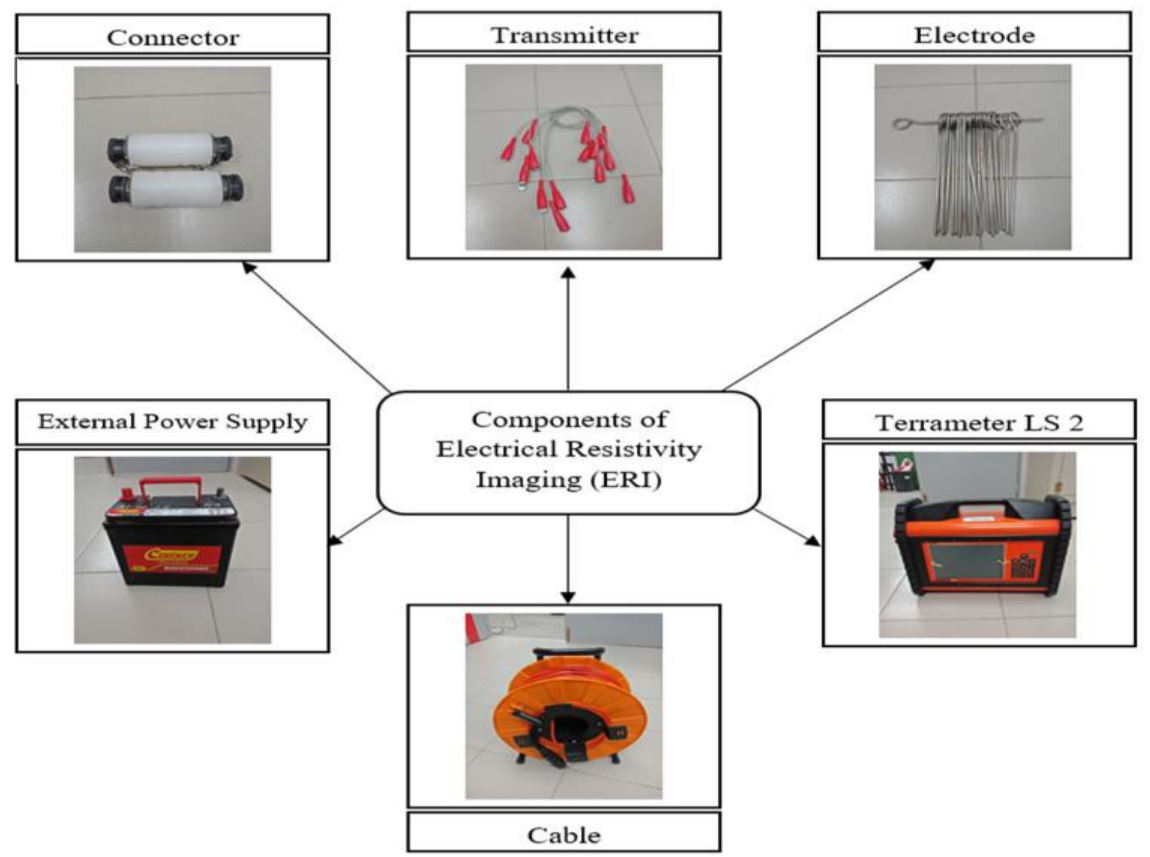

Fig. 4 - ERI components

The coordinate of the resistivity survey line were tabulated in Table 1 . The coordinate of the survey line were taken at two points which is at the first and last electrode injected into the ground during the resistivity survey with the total survey length of $400 \mathrm{~m}$ per resistivity survey line. The resistivity survey line are presented in red line as shown in Fig. 2 and Fig. 3.

The survey was carried out using an ABEM LS 2 Terrameter with 61 electrodes separated at $5 \mathrm{~m}$ for the inner spacing and $10 \mathrm{~m}$ for the outer spacing. The total length of survey spread was $400 \mathrm{~m}$ for resistivity survey line 1 (R1), resistivity survey line 2 (R2), resistivity survey line 3 (R3), resistivity survey line 4 (R4), resistivity survey line 5 (R5), resistivity survey line 6 (R6) and resistivity survey line 7 (R7). The pre-survey data of the resistivity is tabulated in Table 2. The arrangement of the ERI components are clearly illustrated in Fig. 5. 
Table 1 - Coordinate of resistivity survey line

\begin{tabular}{|c|c|c|}
\hline Survey Line & First Point & Last Point \\
\hline \multirow[b]{2}{*}{ R1 } & $1^{0} 48^{\prime} 10.0^{\prime \prime} \mathrm{N}$ & $1^{0} 48^{\prime} 10.6 ” \mathrm{~N}$ \\
\hline & $102^{0} 55^{\prime} 24.5^{\prime \prime} \mathrm{E}$ & $102^{0} 55^{\prime} 36.6$ "E \\
\hline \multirow[b]{2}{*}{ R2 } & $1^{0} 48^{\prime} 20.1^{\prime \prime} \mathrm{N}$ & $1^{0} 48^{\prime} 18.2^{\prime \prime} \mathrm{N}$ \\
\hline & $102^{0} 55^{\prime} 18.7^{\prime \prime} \mathrm{E}$ & $102^{0} 55^{\prime} 36.4^{\prime \prime} \mathrm{E}$ \\
\hline \multirow{2}{*}{ R3 } & $1^{0} 48^{\prime} 17.7^{\prime \prime} \mathrm{N}$ & $1^{0} 48^{\prime} 07.4{ }^{\prime \prime} \mathrm{N}$ \\
\hline & $102^{0} 55^{\prime} 14.2^{\prime \prime} \mathrm{E}$ & $102^{0} 55^{\prime} 26.2^{\prime \prime} \mathrm{E}$ \\
\hline \multirow[b]{2}{*}{ R4 } & $1^{0} 48^{\prime} 17.5^{\prime \prime} \mathrm{N}$ & $1^{0} 48^{\prime} 14.1 " \mathrm{~N}$ \\
\hline & $102^{0} 55^{\prime} 34.0^{\prime \prime} \mathrm{E}$ & $102^{0} 55^{\prime} 33.0^{\prime \prime} \mathrm{E}$ \\
\hline \multirow[b]{2}{*}{ R5 } & $1^{0} 48^{\prime} 15.0 ” \mathrm{~N}$ & $1^{0} 48^{\prime} 00.7^{\prime \prime} \mathrm{N}$ \\
\hline & $102^{0} 55^{\prime} 20.4$ 'Е & $102^{0} 55^{\prime} 25.5^{\prime \prime} \mathrm{E}$ \\
\hline \multirow{2}{*}{ R6 } & $1^{0} 48^{\prime} 17.5^{\prime \prime} \mathrm{N}$ & $1^{0} 48^{\prime} 00.3^{\prime \prime} \mathrm{N}$ \\
\hline & $102^{0} 55^{\prime} 34.0^{\prime \prime} \mathrm{E}$ & $102^{0} 55^{\prime} 36.6$ " $\mathrm{E}$ \\
\hline \multirow{2}{*}{ R7 } & $1^{0} 48^{\prime} 08.4$ 'N & $1^{0} 48^{\prime} 06.9^{\prime \prime} \mathrm{N}$ \\
\hline & $102^{0} 55^{\prime} 37.3^{\prime \prime} \mathrm{E}$ & $102^{0} 55^{\prime} 46.2^{\prime \prime} \mathrm{E}$ \\
\hline
\end{tabular}

Table 2 - ERI pre-survey data

\begin{tabular}{cccccc}
\hline Survey Line & Cable Used & $\begin{array}{c}\text { Cable } \\
\text { Length } \\
(\mathbf{m})\end{array}$ & $\begin{array}{c}\text { Spacing } \\
\text { (Inner } \\
\text {,Outer) }(\mathbf{m})\end{array}$ & $\begin{array}{c}\text { Survey } \\
\text { Length } \\
(\mathbf{m})\end{array}$ & $\begin{array}{c}\text { Borehole } \\
\text { Number }\end{array}$ \\
\hline R1 & 4 & 100 & 5,10 & 400 & BH1 \\
R2 & 4 & 100 & 5,10 & 400 & BH2 \\
R3 & 4 & 100 & 5,10 & 400 & BH4 \\
R4 & 4 & 100 & 5,10 & 400 & BH3 \\
R5 & 4 & 100 & 5,10 & 400 & BH6 \\
R6 & 4 & 100 & 5,10 & 400 & - \\
R7 & 4 & 100 & 5,10 & 400 & - \\
\hline
\end{tabular}

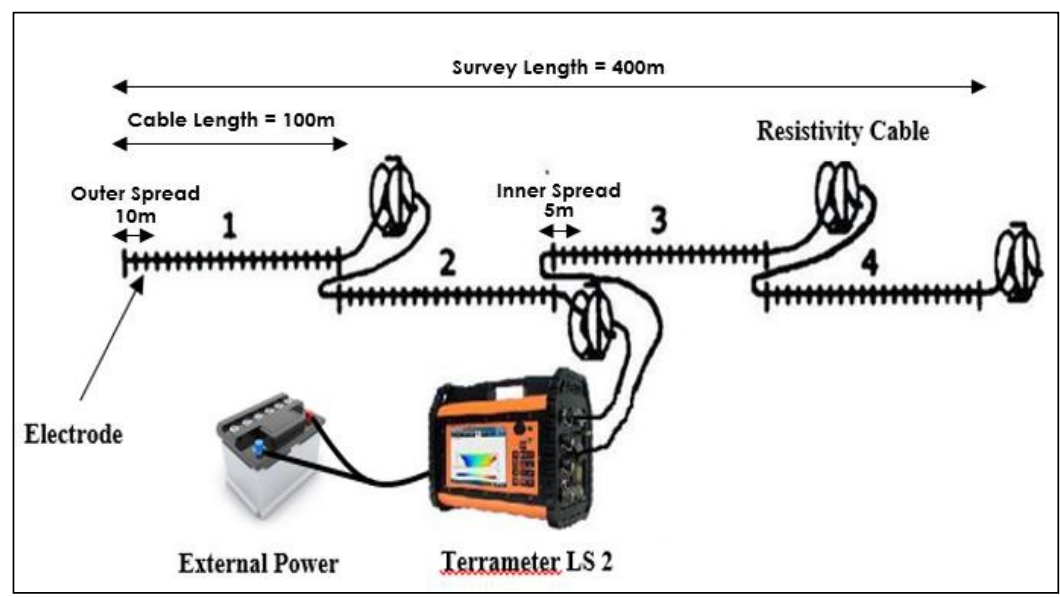

Fig. 5 - Electrical Resistivity Imaging (ERI) component arrangement

Data was recorded using Schlumberger protocol. It gives a dense near-surface covers, and a slightly sparser measurement pattern at long electrode spacing. The data collected in the field are processed using RES2DINV software. Resistivity method basically measures the resistivity distribution of the subsurface material. Table 3 shows the resistivity value of some of the typical rocks, soil materials and water [22] that were referred to carry out the resistivity analysis.

Besides, the data obtained from the field survey was processed using the RES2DINV software to produce an inverse model of the subsurface profile that roughly having the same structure with the actual subsurface structure [23]. [24] has discussed that the RES2DINV software and inversion algorithm were used to process the data in order to obtain the resistivity section of the subsurface profile. As discussed in section 1.0, owing to the site condition and to the target of interest, the RES2DINV software used the inversion routine which was based on the smooth constrained method to achieve the objectives of the resistivity survey. Based on [24], two-dimensional model used in the subsurface 
were divided by the RES2DINV software into a number of rectangular blocks. When the resistivity images were obtained, the subsurface profiles of the soil were interpreted according to the resistivity value stated by [25].

Table 3 - Resistivity of some common rocks and soil materials [25]

\begin{tabular}{|c|c|}
\hline Material & Resistivity $(\Omega \mathrm{m})$ \\
\hline \multicolumn{2}{|c|}{ Igneous and Metamorphics Rocks } \\
\hline Granite & $5 \times 10^{3}-10^{6}$ \\
\hline Basalt & $10^{3}-10^{6}$ \\
\hline Slate & $6 \times 10^{2}-4 \times 10^{7}$ \\
\hline Marble & $10^{2}-2.5 \times 10^{8}$ \\
\hline Quartzite & $10^{2}-2 \times 10^{8}$ \\
\hline Hematite Ore & $8-1 \times 10^{4}$ \\
\hline Magnetite Ore & $0.1-1 \times 10^{3}$ \\
\hline \multicolumn{2}{|c|}{ Sedimentary Rocks } \\
\hline Sandstone & $8-4 \times 10^{3}$ \\
\hline Shale & $20-2 \times 10^{3}$ \\
\hline Limestone & $50-4 \times 10^{2}$ \\
\hline \multicolumn{2}{|c|}{ Soils and Waters } \\
\hline Clay & $1-100$ \\
\hline Alluvium & $10-800$ \\
\hline Groundwater (Fresh) & $10-100$ \\
\hline Sea water & 0.2 \\
\hline
\end{tabular}

Igneous and metamorphic rocks typically have high resistivity values. As stated by [22], the resistivity of these rocks is mainly dependent on the degree of fracturing. Since the water table in Malaysia is generally shallow, the fractures are commonly filled with ground water. For example, the greater the fracturing, the lower is the resistivity of granite varies from $5 \times 10^{3} \mathrm{ohm} / \mathrm{m}$ in wet condition to $5 \times 10^{6} \mathrm{ohm} / \mathrm{m}$ when it is dry. Soils above the water table is drier and has a higher resistivity value of several hundred to several thousand $\mathrm{ohm} / \mathrm{m}$, while soils below the water table generally have resistivity values of less than $100 \mathrm{ohm} / \mathrm{m}$. Also clay has a significantly lower resistivity than sand. This id due to the conductivity of the soil below water table. The soil and rock below water table is in a wet condition which can conduct the electric current thus lead to low resistivity value.

\section{Results and Discussion}

\subsection{Soil Properties}

The engineering properties of the soils were obtained from the boreholes data. The hardness of the soil for BH1, BH2, BH3, BH4, BH5 AND BH6 were summarized in Table 6, Table 7, Table 8, Table 9, Table 10 and Table 11 respectively.

Rock Quality Designation (RQD) is a measure of quality of rock core taken from a borehole. RQD signifies the degree of jointing or fracture in a rock mass measured in percentage, where RQD of $75 \%$ or more shows good quality hard rock and less than $50 \%$ show low quality weathered rocks. Only those pieces of rocks are considered which are hard and good quality. Weathered rocks which does not meet soundness requirements and whose lengths are not greater than $100 \mathrm{~mm}$ are not considered for calculation of RQD. The length of core pieces is measured along center line of the pieces. Table 5 shows quality of rocks and their RQD.

Based on [26], rock quality can be classified into five (5) groups which is very poor rock quality (completely weathered rock), poor rock quality (weathered rock), fair rock quality (moderately weathered rock), good rock quality (hard rock) and very good rock quality (fresh rock) with the RQD percentage of less than 25\%, 25-30\%, 51-75\%, 76$90 \%$ and $91-100 \%$ respectively. The value stated by [26] were used as a reference in analysis of borehole data of BH1 BH6 of the study.

Table 6 shows the field test of BH 1 data at the study site. Based on Table 6 , it can be clearly seen that at 0.00 $10.80 \mathrm{~m}$ of boring depth, the soil is freely bore until it hit the rock at $10.80 \mathrm{~m}$ with a ground water level of $10.02 \mathrm{~m}$. At $10.80-16.80 \mathrm{~m}$ with a water level of $6.33 \mathrm{~m}$, a fresh granite can be found with a pale grey spotted dark and light brown colour with a RQD value of $90 \%$. Based on the research conducted by [26], this rock can be classified as good rock quality with a strong hard granite. 
Table 5 - Quality of rocks and its respective RQD [26]

\begin{tabular}{|c|c|c|c|}
\hline \multicolumn{2}{|c|}{ Rock Quality } & \multicolumn{2}{|c|}{ RQD (\%) } \\
\hline Complet & $\begin{array}{l}\text { y Poor } \\
\text { Weathered Rock }\end{array}$ & \multicolumn{2}{|c|}{$<25$} \\
\hline$W e$ & ered Rock & \multicolumn{2}{|c|}{$25-30$} \\
\hline Moderat & $\begin{array}{l}\text { Fair } \\
\text { Weathered Rock }\end{array}$ & \multicolumn{2}{|c|}{$51-75$} \\
\hline & $\begin{array}{l}\text { Jood } \\
\text { d Rock }\end{array}$ & \multicolumn{2}{|c|}{$76-90$} \\
\hline & $\begin{array}{l}\text { y Good } \\
\text { sh Rock }\end{array}$ & \multicolumn{2}{|c|}{$91-100$} \\
\hline \multicolumn{4}{|c|}{ Table 6 - Field test of BH 1} \\
\hline $\begin{array}{c}\text { Cumulative } \\
\text { Depth (m) }\end{array}$ & Material Description & $\begin{array}{c}\text { Field Test } \\
\text { Result }\end{array}$ & $\begin{array}{c}\text { Ground Water } \\
\text { Level (m) }\end{array}$ \\
\hline $0.00-10.80$ & $\begin{array}{l}\text { Free bore from in soil } \\
\text { from } 0.00 \mathrm{~m} \text { until hit } \\
\text { rock at } 10.80 \mathrm{~m}\end{array}$ & - & 10.02 \\
\hline $10.80-12.30$ & $\begin{array}{l}\text { Pale grey spotted dark } \\
\text { grey and light brown }\end{array}$ & RQD:90\% & - \\
\hline $12.30-13.80$ & $\begin{array}{l}\text { Pale grey spotted dark } \\
\text { grey }\end{array}$ & RQD:90\% & - \\
\hline $13.80-15.30$ & -ditto- & RQD:90\% & - \\
\hline $15.30-16.80$ & -ditto- & RQD:90\% & 6.33 \\
\hline
\end{tabular}

Table 7 shows the field test of BH 2 data at the study site. Based on Table 7, it can be clearly seen that at 0.00 $15.00 \mathrm{~m}$ of boring depth, the soil is freely bore until it hit the rock at $15.00 \mathrm{~m}$. At $15.00-18.00 \mathrm{~m}$ with a water level of $13.45 \mathrm{~m}$, a fresh granite can be found with a pale grey (white) spotted dark grey colour with a RQD value of ranging from $91 \%$ to $93 \%$. This rock can be classified as very good rock quality with an extremely strong fresh granite. At $18.00-19.50 \mathrm{~m}$, a strong granite was also found with the RQD value of $91 \%$ which can be classified as very good rock quality with an extremely strong fresh granite. The colour of the granite found within this depth is pale grey (white) spotted dark grey and one end light greyish brown. At $19.50-21.00 \mathrm{~m}$ of boring depth with a ground water level of $3.03 \mathrm{~m}$, a light greyish brown spotted dark grey and pale grey spotted dark grey can be found with the RQD value of $100 \%$. This rock can be classified as very good rock quality of fresh granite.

Table 7 - Field test of BH 2

\begin{tabular}{cccc}
\hline $\begin{array}{c}\text { Cumulative } \\
\text { Depth (m) }\end{array}$ & Material Description & $\begin{array}{c}\text { Field Test } \\
\text { Result }\end{array}$ & $\begin{array}{c}\text { Ground Water } \\
\text { Level (m) }\end{array}$ \\
\hline Free bore in soil from & & - \\
$15.00-15.00$ & $\begin{array}{c}\text { 0.00 m until hit rock at } \\
15.00 \mathrm{~m}\end{array}$ & - & - \\
$16.50-18.00$ & $\begin{array}{c}\text { Pale grey (white) spotted } \\
\text { dark grey } \\
\text {-ditto- }\end{array}$ & RQD:91\% & 13.45 \\
$18.00-19.50$ & $\begin{array}{c}\text { Pale grey (white) spotted } \\
\text { dark grey and one end } \\
\text { light greyish brown } \\
\text { Light greyish brown } \\
\text { spotted dark grey and } \\
\text { pale grey spotted dark } \\
\text { grey }\end{array}$ & RQD:91\% & - \\
\hline
\end{tabular}

Table 8 shows the field test of BH 3 data at the study site. Based on Table 8 , it can be clearly seen that at 0.00 $10.00 \mathrm{~m}$ of boring depth, the soil is freely bore until it hit the rock at $10.00 \mathrm{~m}$. At $10.00-11.50 \mathrm{~m}$, a fresh granite can be found with a pale grey (white) spotted dark grey colour with a RQD value of $93 \%$. This rock can be classified as very good rock quality with an extremely strong fresh granite. At $11.50-13.00 \mathrm{~m}$ with a ground water level of $9.50 \mathrm{~m}$, 
a strong granite was also found with the RQD value of $100 \%$ which can be classified as very good rock quality with an extremely strong fresh granite. The colour of the granite found within this depth is light greyish brown pale grey (white) spotted dark grey. At $13.00-16.00 \mathrm{~m}$ of boring depth with a ground water level of $6.30 \mathrm{~m}$ at $16.00 \mathrm{~m}$, a light greyish brown spotted dark grey and pale grey spotted dark grey can be found with the RQD value of $100 \%$. This rock can be classified as very good rock quality of fresh granite.

Table 8 - Field test of BH 3

\begin{tabular}{|c|c|c|c|}
\hline $\begin{array}{c}\text { Cumulative } \\
\text { Depth (m) }\end{array}$ & Material Description & $\begin{array}{c}\text { Field Test } \\
\text { Result }\end{array}$ & $\begin{array}{c}\text { Ground Water } \\
\text { Level (m) }\end{array}$ \\
\hline $0.00-10.00$ & $\begin{array}{c}\text { Free bore in soil from } \\
0.00 \mathrm{~m} \text { until hit rock at } \\
10.00 \mathrm{~m}\end{array}$ & - & - \\
\hline $10.00-11.50$ & $\begin{array}{c}\text { Pale grey (white) spotted } \\
\text { dark grey }\end{array}$ & RQD:93\% & - \\
\hline $11.50-13.00$ & $\begin{array}{l}\text { Light greyish brown pale } \\
\text { grey(white) spotted dark } \\
\text { grey }\end{array}$ & RQD: $100 \%$ & 9.50 \\
\hline $13.00-14.50$ & -ditto- & RQD: $100 \%$ & - \\
\hline $14.50-16.00$ & $\begin{array}{l}\text { Light greyish brown } \\
\text { spotted dark grey and } \\
\text { pale grey spotted dark } \\
\text { grey }\end{array}$ & RQD: $100 \%$ & 6.30 \\
\hline
\end{tabular}

Table 9 shows the field test of BH 4 data at the study site. Based on Table 9, it can be clearly seen that at 0.00 $7.50 \mathrm{~m}$ of boring depth, the soil is freely bore until it hit the rock at $7.50 \mathrm{~m}$. At $7.50-7.80 \mathrm{~m}$ with a ground water level of $2.62 \mathrm{~m}$, a moderately weathered granite can be found with a light yellowish brown spotted dark grey colour with a RQD value of $73 \%$. This rock can be classified as fair rock quality with moderately weathered granite. At 7.80 - 15.00 $\mathrm{m}$ with a ground water level of $7.10 \mathrm{~m}$, the free boring were continue until it hit rock at $15.00 \mathrm{~m}$. At $15.00-16.50 \mathrm{~m}$ of boring depth, a pale grey spotted dark grey can be found with the RQD value of $64 \%$. This rock can be classified as fair rock quality of moderately weathered granite as stated by [26]. At $16.50-18.00 \mathrm{~m}$, a weak granite with a pale grey and light brown colour can be found with the RQD value of $70 \%$. This granite can be classified as fair rock quality of weathered rock.

Table 9 - Field test of BH 4

\begin{tabular}{|c|c|c|c|}
\hline $\begin{array}{l}\text { Cumulative } \\
\text { Depth (m) }\end{array}$ & Material Description & $\begin{array}{c}\text { Field Test } \\
\text { Result }\end{array}$ & $\begin{array}{c}\text { Ground Water } \\
\text { Level (m) }\end{array}$ \\
\hline $0.00-7.50$ & $\begin{array}{c}\text { Free bore in soil from } \\
0.00 \mathrm{~m} \text { until hit rock at } \\
7.50 \mathrm{~m}\end{array}$ & 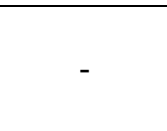 & 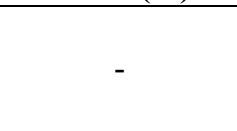 \\
\hline $7.50-7.80$ & $\begin{array}{l}\text { Light yellowish brown } \\
\text { spotted dark grey }\end{array}$ & RQD:73\% & 2.62 \\
\hline $7.80-15.00$ & $\begin{array}{l}\text { Continue free bore in } \\
\text { soil from } 7.80 \mathrm{~m} \text { until hit } \\
\text { rock at } 15.00 \mathrm{~m}\end{array}$ & - & 7.10 \\
\hline $15.00-16.50$ & $\begin{array}{l}\text { Pale grey spotted dark } \\
\text { grey }\end{array}$ & RQD:64\% & - \\
\hline $16.50-18.00$ & $\begin{array}{l}\text { Pale grey and light } \\
\text { brown }\end{array}$ & RQD:70\% & - \\
\hline
\end{tabular}

Table 10 shows the field test of BH 5 data at the study site. Based on Table 10, it can be clearly seen that at 0.00 $3.00 \mathrm{~m}$ of boring depth, the soil is freely bore until it hit the rock at $3.00 \mathrm{~m}$. At $3.00-6.00 \mathrm{~m}$, a strong fresh granite can be found with a pale grey spotted dark grey colour with a RQD value of $91 \%$. This rock can be classified as very good rock quality with extremely strong fresh granite. At $6.00-7.50 \mathrm{~m}$ with a ground water level of $4.20 \mathrm{~m}$, a moderately weathered rock with the RQD value of $53 \%$ can be found. The colour of this rock is pale grey spotted dark grey and can be classified as fair rock quality. At $7.50-9.00 \mathrm{~m}$ of boring depth with a ground water level of $2.40 \mathrm{~m}$, a pale grey spotted dark grey can be found with the RQD value of $91 \%$. This rock can be classified as very good rock quality of strong fresh granite as stated by [26].

Table 11 shows the field test of BH 6 data at the study site. Based on Table 11, it can be clearly seen that at 0.00 $2.60 \mathrm{~m}$ of boring depth, the soil is freely bore until it hit the rock at $2.60 \mathrm{~m}$. At $2.60-4.10 \mathrm{~m}$, a strong fresh granite can 
be found with a pale grey spotted dark grey colour with a RQD value of $80 \%$. This rock can be classified as good rock quality with hard granite. At $4.10-5.60 \mathrm{~m}$ with a ground water level of $4.05 \mathrm{~m}$, an extremely strong fresh granite rock with the RQD value of $90 \%$ can be found. The colour of this rock is pale grey spotted dark grey and can be classified as good rock quality. At $5.60-7.10 \mathrm{~m}$ of boring depth, a pale grey spotted dark grey and light brown can be found with the RQD value of $76 \%$. This rock can be classified as good rock quality of strong fresh granite as stated by [26]. At $7.10-8.60 \mathrm{~m}$ with a ground water level of $3.15 \mathrm{~m}$, a moderate weathered granite can be found with the RQD value of $85 \%$. The colour of the granite found within this depth is pale grey spotted grey and light brown and can be classified as good rock quality with a hard rock.

Based on the field test result of the six (6) boreholes, it come to the agreement that granite rock were found in most of the area of study starting with the RQD of $13 \%$ to $100 \%$. The strongest fresh granite were found in BH3 (at 11.50 $13.00 \mathrm{~m}$ depth and $14.50-16.00 \mathrm{~m}$ depth) and in BH2 (at $19.50-21.00 \mathrm{~m}$ depth). The moderate strength of granite rock was found in BH4 (at 7.50 - $7.80 \mathrm{~m}$ depth and 16.50 - $18.00 \mathrm{~m}$ depth), BH5 (at $6.00-7.50 \mathrm{~m}$ depth) and BH6 (at $7.10-8.60 \mathrm{~m}$ depth).

Table 10 - Field test of BH 5

\begin{tabular}{cccc}
\hline $\begin{array}{c}\text { Cumulative } \\
\text { Depth (m) }\end{array}$ & Material Description & $\begin{array}{c}\text { Field Test } \\
\text { Result }\end{array}$ & $\begin{array}{c}\text { Ground Water } \\
\text { Level (m) }\end{array}$ \\
\hline $0.00-3.00$ & $\begin{array}{c}\text { Free bore in soil from } \\
0.00 \text { m until hit rock at } \\
3.00 \mathrm{~m}\end{array}$ & - & - \\
$3.00-4.50$ & $\begin{array}{c}\text { Pale grey spotted dark } \\
\text { grey }\end{array}$ & RQD:91\% & - \\
$4.50-6.00$ & $\begin{array}{c}\text { Pale grey spotted dark } \\
\text { grey }\end{array}$ & RQD:91\% & - \\
$6.00-7.50$ & $\begin{array}{c}\text { Pale grey spotted dark } \\
\text { grey }\end{array}$ & RQD:53\% & 4.20 \\
$7.50-9.00$ & $\begin{array}{c}\text { Pale grey spotted dark } \\
\text { grey }\end{array}$ & RQD:91\% & 2.40 \\
\hline
\end{tabular}

Table 11 - Field test of BH 6

\begin{tabular}{|c|c|c|c|}
\hline $\begin{array}{c}\text { Cumulative } \\
\text { Depth (m) }\end{array}$ & Material Description & $\begin{array}{c}\text { Field Test } \\
\text { Result }\end{array}$ & $\begin{array}{c}\text { Ground Water } \\
\text { Level (m) }\end{array}$ \\
\hline $0.00-2.60$ & $\begin{array}{c}\text { Free bore in soil from } \\
0.00 \mathrm{~m} \text { until hit rock at } \\
2.60 \mathrm{~m}\end{array}$ & - & - \\
\hline $2.60-4.10$ & $\begin{array}{l}\text { Pale grey spotted dark } \\
\text { grey }\end{array}$ & RQD:80\% & - \\
\hline $4.10-5.60$ & -ditto- & RQD:90\% & 4.05 \\
\hline $5.60-7.10$ & $\begin{array}{l}\text { Pale grey spotted dark } \\
\text { grey and light brown }\end{array}$ & RQD:76\% & - \\
\hline $7.10-8.60$ & $\begin{array}{l}\text { Pale grey spotted dark } \\
\text { grey and light brown }\end{array}$ & RQD: $85 \%$ & 3.15 \\
\hline
\end{tabular}

\subsection{Electrical Resistivity Imaging (ERI) Analysis}

Interpreted 2-D electrical resistivity profiles are presented in Fig. 6 to Fig. 12, horizontal scale in meters for length of survey lines and vertical scale in meters for elevation. Total of seven (7) electrical resistivity lines were designed to run within the interested area as shown in Fig. 2 and Fig. 3. The maximum depths with data coverage at centre portion of survey lines for Schlumberger protocol are between $75.00-85.00 \mathrm{~m}$ respectively. The results of the $2 \mathrm{D}$ resistivity imaging obtained from the R1 to R7 surveys line revealed three (3) types of materials as recorded in Table 12.

The resistivity value exhibits a wide range between $100 \Omega \mathrm{m}$ to more than $2000 \Omega \mathrm{m}$. The resistivity value of more than $2000 \Omega \mathrm{m}$ which is presented in dark red and purple colour in the resistivity profile were interpreted as solid granite body that was found dominantly at the survey area. The solid granite is varying in depth ranging between 15 $45 \mathrm{~m}$ from the overburden soil. It is also found that some granite bodies were detected near to surface, which estimated about $8.00-10.00 \mathrm{~m}$ below ground surface.

The resistivity value of $1200 \Omega \mathrm{m}-2000 \Omega \mathrm{m}$ presented in the processed ERI profiles are in greenish and yelloworange colour, they are interpreted as fractured/jointing granite with present of ground water in these joints. The very 
low resistivity value range between $20 \Omega \mathrm{m}-1200 \Omega \mathrm{m}$ is occurred probably due to the presence of the highly fractured zone with the water saturation.

Table 12 - Interpretation of resistivity value in Batu Pahat area

\begin{tabular}{|c|c|c|c|}
\hline No & $\begin{array}{c}\text { Resistivity Value } \\
(\Omega \mathrm{m})\end{array}$ & Resistivity Legend & Interpretation \\
\hline 1 & $100-1000$ & $0.00=500$ & Overburden Soils \\
\hline 2 & $1200-2000$ & $\underset{1200}{\square}$ & $\begin{array}{c}\text { Fractured GRANITE } \\
\text { with present of } \\
\text { groundwater }\end{array}$ \\
\hline 3 & More than 2000 & ש들 & Solid GRANITE \\
\hline
\end{tabular}

The overburden soil of the survey area consists of various soil types and properties. However, the main soil types observed are silty sand with mixture or organic matter (humus) and sand at the stream. The variation of soil types had contributed to the wide range of resistivity value from $100 \Omega \mathrm{m}$ to $1000 \Omega \mathrm{m}$. The resistivity value of range $100 \Omega \mathrm{m}$ to $1000 \Omega \mathrm{m}$ are presented in light greenish to reddish colour and it is interpreted as layer of overburden soil at the upper part of the resistivity profile. Based on the seven (7) resistivity profile obtained, the overburden soil thickness range between $8.00-25.00 \mathrm{~m}$. Granite boulders probably presence in this layer due to increasing of the resistivity value obtained.

Fig. 6 shows the resistivity result of resistivity survey line 1 (R1) conducted at the site of the study. Based on the figure, there are five (5) main zone highlighted in the study that is saturated zone, overburden soil, boulders, solid granite and fractured granite. Based on Table 12 and as stated by [25], the saturated zone (very dark blue colour) are identified 5 to $10 \mathrm{~m}$ below the surface of the soil with the range of resistivity value of $0-100 \Omega \mathrm{m}$. The soil at this area are expected to be in wet conditions due to the conductivity of electric current and low resistivity value.

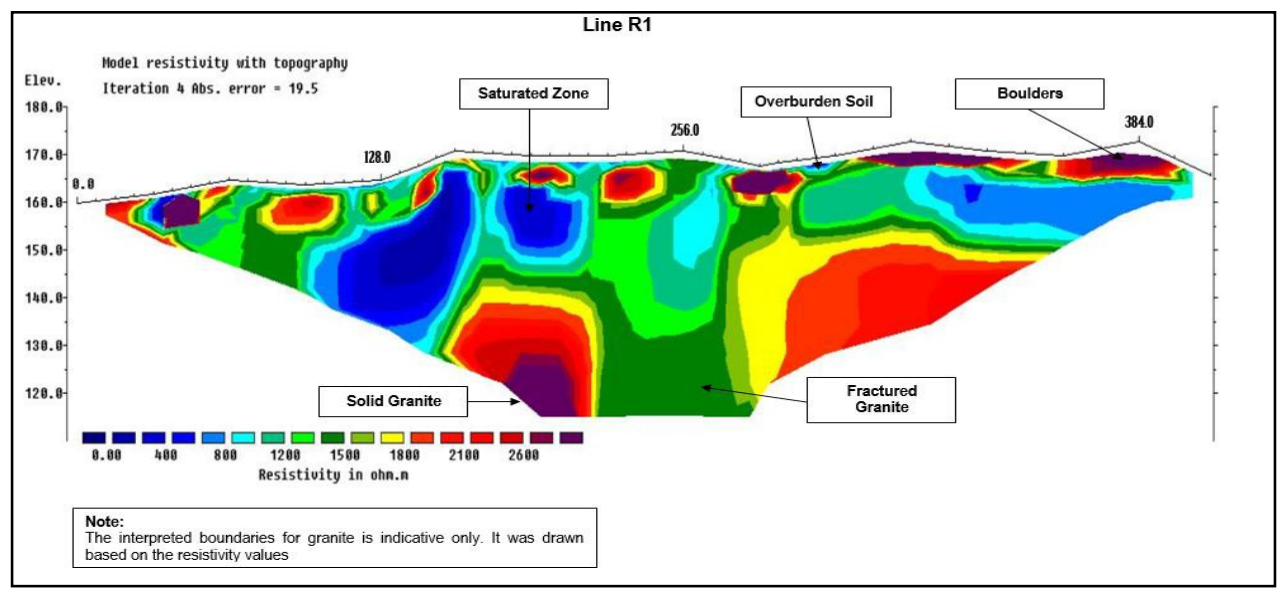

Fig. 6 - Resistivity result of resistivity survey line 1 (R1)

The overburden soil (blue colour) are identified near the surface of the soils with the range of resistivity value of $100-1000 \Omega \mathrm{m}$. The water content of the soil at this area are expected to be lower than saturated zone as it has higher resistivity value compared to the saturated zone. The boulders (orange to light purple) are identified near the surface of the soil with the range of resistivity value of more than $2000 \Omega \mathrm{m}$. The soil at this area are expected to be in a dry condition as it resist the flow of electric current and the resistivity value is higher at this region. The fractured granite (green to yellow) are identified from the surface of the soil to the depth of $40 \mathrm{~m}$ with the range of resistivity value of $1200-2000 \Omega \mathrm{m}$. At this region, the subsurface material are identified as fractured granite with present of groundwater as the resistivity value is lower at this region as compared to the solid granite region.

The solid granite (red to dark purple) are identified at the depth of $45 \mathrm{~m}$ from the surface of the soil with the range of resistivity value of more than $2000 \Omega \mathrm{m}$. The subsurface material are identified as solid granite due to the high resistivity value and the moisture content of the material are expected to be lowered as the resistivity value at this region is high. Below groundwater level, the resistivity value of the subsurface material is low. Thus, it can be proved that the identified material is not dry soil as the resistivity value is high and can be classified as solid granite according to the resistivity value stated by [25]. The different between boulders and solid granite is that the boulders are found near the surface of the soil while the solid granite are mainly found more than $10 \mathrm{~m}$ below the surface of the soil. 
Fig. 7 shows the resistivity result of resistivity survey line 2 (R2) conducted at the site of the study. Based on the figure, there are five (5) main zone highlighted in the study that is saturated zone, overburden soil, boulders, solid granite and fractured granite. The conditions for saturated zone, overburden soil and boulders are the same as discussed in previous figure.

The fractured granite (yellow) are identified from the surface of the soil to the depth of $10 \mathrm{~m}$ with the range of resistivity value of $1200-2000 \Omega \mathrm{m}$. At this region, the subsurface material are identified as fractured granite with present of groundwater as the resistivity value is lower at this region as compared to the solid granite region. The fractured granite are hardly found in R2.

The solid granite (dark purple) are identified at the depth of $45 \mathrm{~m}$ from the surface of the soil with the range of resistivity value of more than $2000 \Omega \mathrm{m}$. The subsurface material are identified as solid granite due to the high resistivity value and the moisture content of the material are expected to be lowered as the resistivity value at this region is high. Below groundwater level, the resistivity value of the subsurface material is low. Thus, it can be proved that the identified material is not dry soil as the resistivity value is high and can be classified as solid granite according to the resistivity value stated by [25]. In this survey line, the solid granite are mainly found.

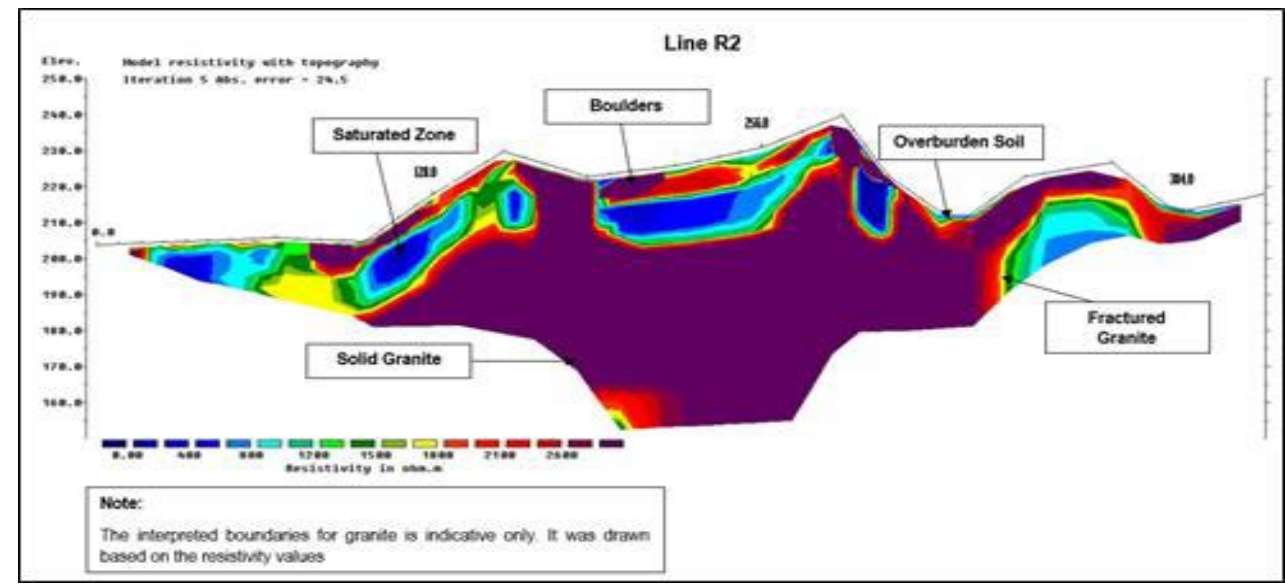

Fig. 7 - Resistivity result of resistivity survey line 2 (R2)

Fig. 8 shows the resistivity result of resistivity survey line 3 (R3) conducted at the site of the study. Based on the figure, there are five (5) main zone highlighted in the study that is saturated zone, overburden soil, boulders, solid granite and fractured granite. The conditions for saturated zone, overburden soil and boulders are the same as discussed in previous figure.

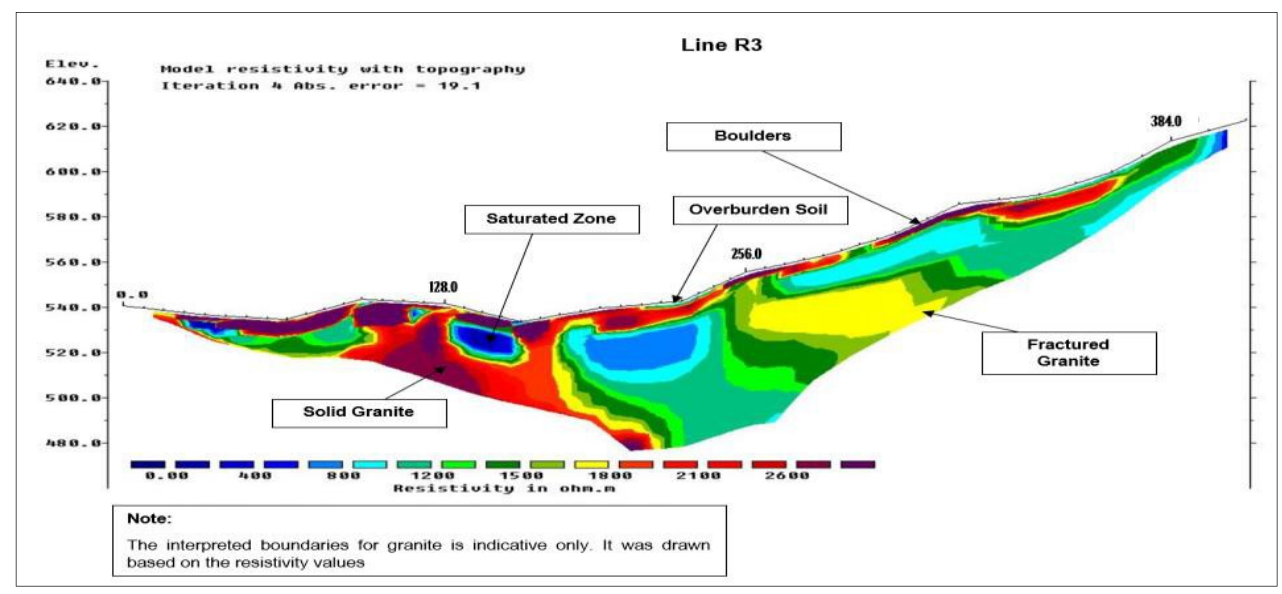

Fig. 8 - Resistivity result of resistivity survey line 3 (R3)

The fractured granite (green to yellow) are identified from the surface of the soil to the depth of $10 \mathrm{~m}$ with the range of resistivity value of $1200-2000 \Omega \mathrm{m}$. At this region, the subsurface material are identified as fractured granite with present of groundwater as the resistivity value is lower at this region as compared to the solid granite region. The fractured granite are mainly identified in this survey line.

The solid granite (red to dark purple) are identified at the depth of $20 \mathrm{~m}$ from the surface of the soil with the range of resistivity value of more than $2000 \Omega \mathrm{m}$. The subsurface material are identified as solid granite due to the high resistivity value and the moisture content of the material are expected to be lowered as the resistivity value at this 
region is high. Below groundwater level, the resistivity value of the subsurface material is low. Thus, it can be proved that the identified material is not dry soil as the resistivity value is high and can be classified as solid granite according to the resistivity value stated by [25]. In this survey line, the solid granite are hardly being identified.

Fig. 9 shows the resistivity result of resistivity survey line 4 (R4) conducted at the site of the study. Based on the figure, there are five (5) main zone highlighted in the study that is saturated zone, overburden soil, boulders, solid granite and fractured granite. The conditions for saturated zone, overburden soil and boulders are the same as discussed in previous figure.

The fractured granite (green to yellow) are identified from the surface of the soil to the depth of $10 \mathrm{~m}$ with the range of resistivity value of $1200-2000 \Omega \mathrm{m}$. At this region, the subsurface material are identified as fractured granite with present of groundwater as the resistivity value is lower at this region as compared to the solid granite region. The fractured granite are mainly identified in this survey line.

The solid granite (red to dark purple) are identified at the depth of $20 \mathrm{~m}$ from the surface of the soil with the range of resistivity value of more than $2000 \Omega \mathrm{m}$. The subsurface material are identified as solid granite due to the high resistivity value and the moisture content of the material are expected to be lowered as the resistivity value at this region is high. Below groundwater level, the resistivity value of the subsurface material is low. Thus, it can be proved that the identified material is not dry soil as the resistivity value is high and can be classified as solid granite according to the resistivity value stated by [25]. In this survey line, the solid granite are also mainly being identified.

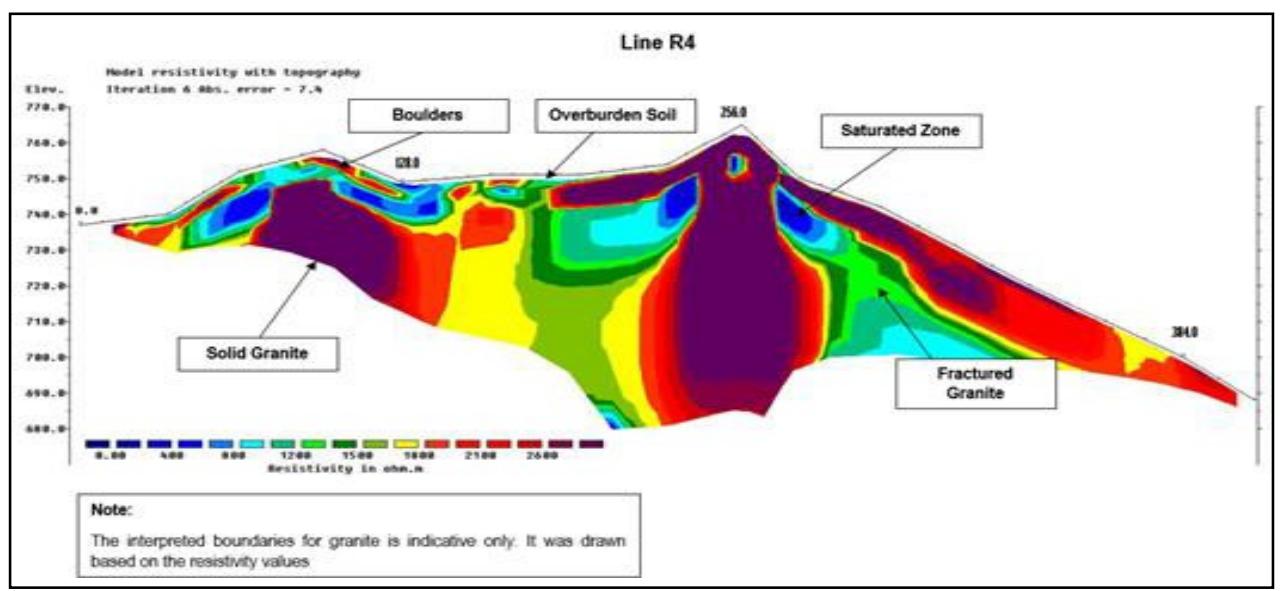

Fig. 9 - Resistivity result of resistivity survey line 4 (R4)

Fig. 10 shows the resistivity result of resistivity survey line 5 (R5) conducted at the site of the study. Based on the figure, there are five (5) main zone highlighted in the study that is saturated zone, overburden soil, boulders, solid granite and fractured granite. The conditions for saturated zone, overburden soil and boulders are the same as discussed in previous figure.

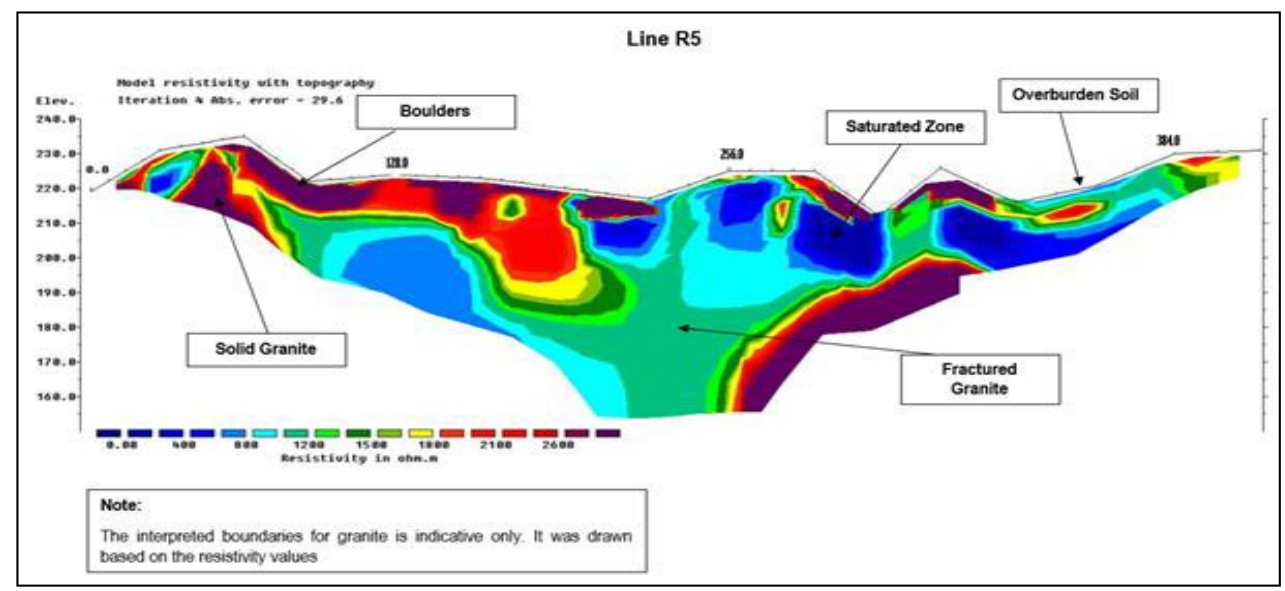

Fig. 10 - Resistivity result of resistivity survey line 5 (R5)

The fractured granite (green to yellow) are identified from the surface of the soil to the depth of $10 \mathrm{~m}$ with the range of resistivity value of $1200-2000 \Omega$ m. At this region, the subsurface material are identified as fractured granite with present of groundwater as the resistivity value is lower at this region as compared to the solid granite region. The fractured granite are mainly identified in this survey line. 
The solid granite (dark purple) are identified at the depth of $20 \mathrm{~m}$ from the surface of the soil with the range of resistivity value of more than $2000 \Omega \mathrm{m}$. The subsurface material are identified as solid granite due to the high resistivity value and the moisture content of the material are expected to be lowered as the resistivity value at this region is high. Below groundwater level, the resistivity value of the subsurface material is low. Thus, it can be proved that the identified material is not dry soil as the resistivity value is high and can be classified as solid granite according to the resistivity value stated by [25]. In this survey line, the solid granite are identified but not mainly as fractured granite.

Fig. 11 shows the resistivity result of resistivity survey line 6 (R6) conducted at the site of the study. Based on the figure, there are four (4) main zone highlighted in the study that is saturated zone, boulders, solid granite and fractured granite. The conditions for saturated zone and boulders are the same as discussed in previous figure.

The fractured granite (green to yellow) are identified from the surface of the soil to the depth of $10 \mathrm{~m}$ with the range of resistivity value of $1200-2000 \Omega \mathrm{m}$. At this region, the subsurface material are identified as fractured granite with present of groundwater as the resistivity value is lower at this region as compared to the solid granite region. The fractured granite are hardly identified in this survey line.

The solid granite (red to dark purple) are identified at the depth of $20 \mathrm{~m}$ from the surface of the soil with the range of resistivity value of more than $2000 \Omega \mathrm{m}$. The subsurface material are identified as solid granite due to the high resistivity value and the moisture content of the material are expected to be lowered as the resistivity value at this region is high. Below groundwater level, the resistivity value of the subsurface material is low. Thus, it can be proved that the identified material is not dry soil as the resistivity value is high and can be classified as solid granite according to the resistivity value stated by [25]. In this survey line, the solid granite are mainly being identified.

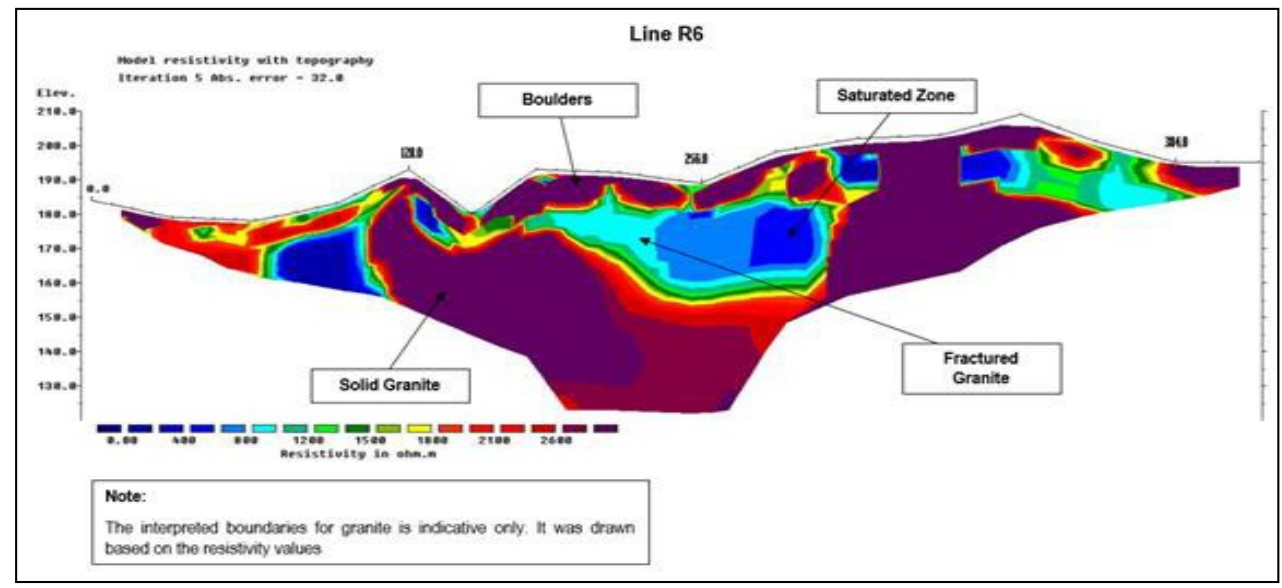

Fig. 11 - Resistivity result of resistivity survey line 6 (R6)

Fig. 12 shows the resistivity result of resistivity survey line 7 (R7) conducted at the site of the study. Based on the figure, there are five (5) main zone highlighted in the study that is saturated zone, overburden soil, boulders, solid granite and fractured granite. The conditions for saturated zone, overburden soil and boulders are the same as discussed in previous figure.

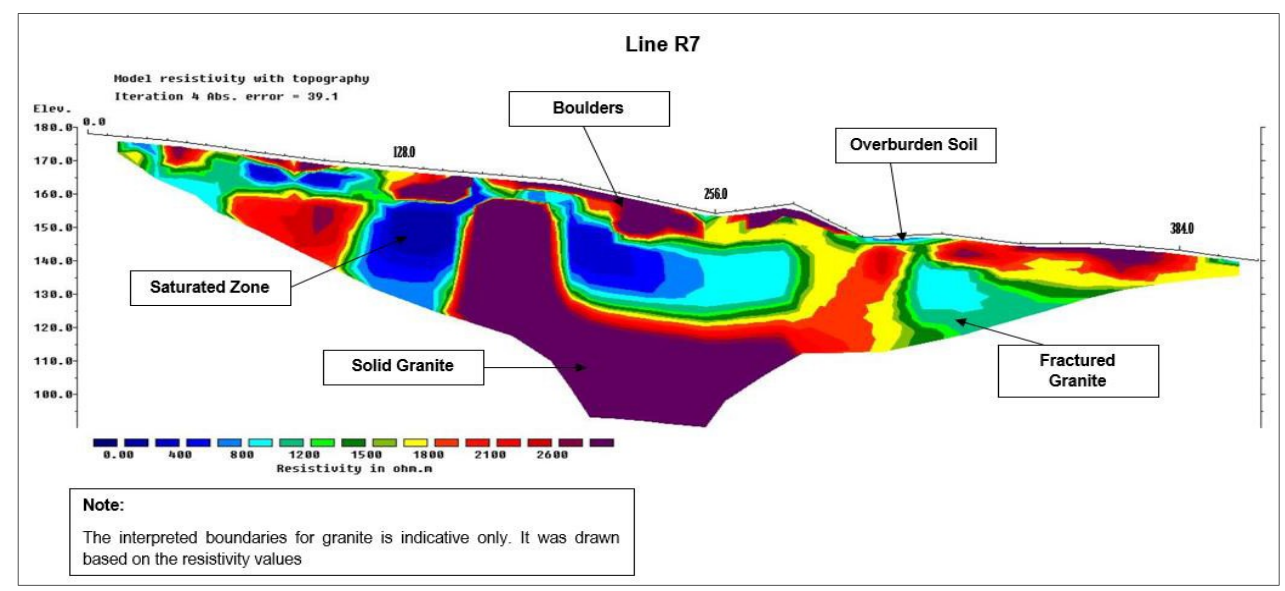

Fig. 12 - Resistivity result of resistivity survey line 7 (R7) 
The fractured granite (green to yellow) are identified from the surface of the soil to the depth of $10 \mathrm{~m}$ with the range of resistivity value of 1200 - $2000 \Omega \mathrm{m}$. At this region, the subsurface material are identified as fractured granite with present of groundwater as the resistivity value is lower at this region as compared to the solid granite region. The fractured granite can be identified in this survey line.

The solid granite (dark purple) are identified at the depth of $20 \mathrm{~m}$ from the surface of the soil with the range of resistivity value of more than $2000 \Omega \mathrm{m}$. The subsurface material are identified as solid granite due to the high resistivity value and the moisture content of the material are expected to be lowered as the resistivity value at this region is high. Below groundwater level, the resistivity value of the subsurface material is low. Thus, it can be proved that the identified material is not dry soil as the resistivity value is high and can be classified as solid granite according to the resistivity value stated by [25]. In this survey line, the solid granite are mainly being identified.

Based on Fig. 6 to Fig. 12, it can be concluded that the solid granite mainly detected in resistivity survey line of R2, R4, R6 and R7 and fractured granite majorly detected in resistivity survey line of R1, R5 and R3. Lastly, the overburden soil are detected mostly at the surface of the soil between the depths of $1.00-3.00 \mathrm{~m}$ below the surface.

\subsection{Comparison of Resistivity and Borehole Field Test Result}

A comparison between the borehole field test result and resistivity value for BH1-R1, BH2-R2, BH3-R4, BH4-R4 and BH6-R5 were made and tabulated in Table 12 to Table 16. Based on the result, it showed that the resistivity value increased when the strength of the granite rock increase. Fig. 12 to Fig. 16 shows clear illustration of the resistivity imaging with the borehole field test result.

As mentioned before, Rock Quality Designation (RQD) is a measure of quality of rock core taken from a borehole. RQD signifies the degree of jointing or fracture in a rock mass measured in percentage, where RQD of $75 \%$ or more shows good quality hard rock and less than $50 \%$ show low quality weathered rocks. Only those pieces of rocks are considered which are hard and good quality. Weathered rocks which does not meet soundness requirements and whose lengths are not greater than $100 \mathrm{~mm}$ are not considered for calculation of RQD. The length of core pieces is measured along center line of the pieces.

Table 13 shows the comparison of borehole field test result of BH1 and resistivity survey line 1 (R1) result conducted at the study site. Fig. 13 illustrates the borehole field test with resistivity imaging of BH1-R1. Based on the result tabulated in Table 13 and illustrated in Fig. 13, the results showed a good agreement between the borelog profiles and resistivity values. The subsurface with low resistivity value were interpreted as overburden soil (mainly silty sand) which was represented by dark blue to blue colour with the range of resistivity values of $100-1000 \Omega \mathrm{m}$ whereas, the high resistivity values were interpreted as solid granite which was represented by red to dark purple colour at the depth of $10 \mathrm{~m}$ from the surface with the range of resistivity value of more than $2000 \Omega \mathrm{m}$. The resistivity value which is a little bit lower than solid granite with the range of resistivity value of $1200-2000 \Omega \mathrm{m}$ is classified as fractured granite which was represented by light green to yellow colour.

Table 13 - Comparison of borehole field test result of BH1 and resistivity survey line R1 (BH1-R1)

\begin{tabular}{|c|c|c|c|}
\hline Depth (m) & Borehole Field Test Result & $\begin{array}{c}\text { Resistivity Value } \\
(\Omega \mathrm{m})\end{array}$ & $\begin{array}{c}\text { Ground Water } \\
\text { Level (m) }\end{array}$ \\
\hline $10.80-12.30$ & $\begin{array}{c}\text { RQD:90\% } \\
\text { (Pale grey spotted dark grey and } \\
\text { light brown) }\end{array}$ & $\begin{array}{c}\mathbf{1 7 0 0} \mathbf{- 1 8 0 0} \\
(\text { Yellow colour - } \\
\text { Fractured GRANITE) }\end{array}$ & 10.02 \\
\hline $12.30-13.80$ & $\begin{array}{c}\text { RQD:90\% } \\
\text { (Pale grey spotted dark grey) }\end{array}$ & $\begin{array}{c}\mathbf{1 8 0 0}-\mathbf{2 0 0 0} \\
(\text { Orange colour - } \\
\text { Fractured GRANITE) }\end{array}$ & - \\
\hline $13.80-15.30$ & $\begin{array}{c}\text { RQD:90\% } \\
\text { (Pale grey spotted dark grey) }\end{array}$ & $\begin{array}{c}\mathbf{1 8 0 0}-\mathbf{2 0 0 0} \\
\text { (Orange colour - } \\
\text { Fractured GRANITE) }\end{array}$ & - \\
\hline $15.30-16.80$ & $\begin{array}{c}\text { RQD:90\% } \\
\text { (Pale grey spotted dark grey) }\end{array}$ & $\begin{array}{c}\mathbf{1 8 0 0}-\mathbf{2 0 0 0} \\
\text { (Orange colour - } \\
\text { Fractured GRANITE) }\end{array}$ & 6.33 \\
\hline
\end{tabular}

However, the resistivity image cannot differentiate the type of material either hard material or rock. Since the resistivity image covers large area, therefore, the resistivity value is taken in a big range. The resistivity value was analysed by referring to [25] and the borehole field test result. At the depth of $10.80-16.80 \mathrm{~m}$, the fractured granite was identified with the RQD value of $90 \%$ (good rock quality identified as hard rock) and the range of resistivity value of $1700-2000 \Omega \mathrm{m}$. The ground water level was found at two (2) different depth which is at the depth of $12.30 \mathrm{~m}$ $(\mathrm{GWL}=10.02 \mathrm{~m})$ and $16.80 \mathrm{~m}(\mathrm{GWL}=6.33 \mathrm{~m})$. If the material have high resistivity value when the GWL is exists, it show that the material identified is solid granite but when the resistivity value is slightly lower than solid granite, it is 
identified as fractured granite. The ground water level became one of the main factor that can be used to differentiate the subsurface material found in this area. Most of the fractured granite identified in this region are pale grey spotted dark grey which is found at the depth of $12.30-16.80 \mathrm{~m}$ while the pale grey spotted dark grey and light brown fractured granite was found at the depth of $10.80-12.30 \mathrm{~m}$.

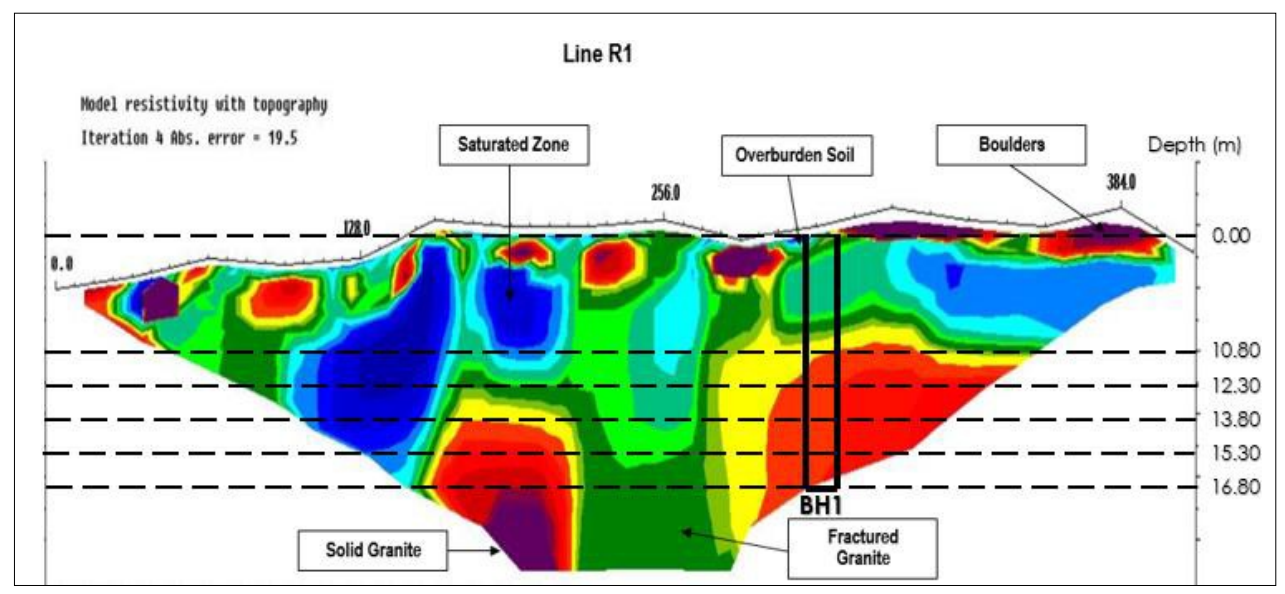

Fig. 13 - Borehole field test with resistivity imaging of BH1-R1

Table 14 shows the comparison of borehole field test result of $\mathrm{BH} 2$ and resistivity survey line 2 (R2) result conducted at the study site. Fig. 14 illustrates the borehole field test with resistivity imaging of BH2-R2. Based on the result tabulated in Table 14 and illustrated in Fig. 14, the results showed a good agreement between the borelog profiles and resistivity values. The subsurface with low resistivity value were interpreted as overburden soil (mainly silty sand) which was represented by dark blue to blue colour with the range of resistivity values of $100-1000 \Omega \mathrm{m}$ whereas, the high resistivity values were interpreted as solid granite which was represented by red to dark purple colour at the depth of $10 \mathrm{~m}$ from the surface with the range of resistivity value of more than $2000 \Omega \mathrm{m}$. The resistivity value which is a little bit lower than solid granite with the range of resistivity value of $1200-2000 \Omega \mathrm{m}$ is classified as fractured granite which was represented by light green to yellow colour. However, the resistivity image cannot differentiate the type of material either hard material or rock.

Table 14 - Comparison of borehole field test result of BH2 and resistivity survey line R2 (BH2-R2)

\begin{tabular}{|c|c|c|c|}
\hline Depth (m) & Borehole Field Test Result & $\begin{array}{c}\text { Resistivity Value } \\
(\Omega \mathrm{m})\end{array}$ & $\begin{array}{r}\text { Ground W: } \\
\text { Level (m }\end{array}$ \\
\hline $15.00-16.50$ & $\begin{array}{c}\text { RQD:91\% } \\
\text { (Pale grey (white) spotted dark } \\
\text { grey) }\end{array}$ & $\begin{array}{c}\text { Over } \mathbf{2 6 0 0} \\
\text { (Purple colour- } \\
\text { Solid GRANITE) }\end{array}$ & - \\
\hline $16.50-18.00$ & $\begin{array}{c}\text { RQD:93\% } \\
\text { (Pale grey (white) spotted dark } \\
\text { grey) }\end{array}$ & $\begin{array}{c}\text { Over } \mathbf{2 6 0 0} \\
\text { (Purple colour - } \\
\text { Solid GRANITE) }\end{array}$ & 13.45 \\
\hline $18.00-19.50$ & $\begin{array}{c}\text { RQD:91\% } \\
\text { (Pale grey (white) spotted dark } \\
\text { grey and one end light greyish } \\
\text { brown) }\end{array}$ & $\begin{array}{c}\text { Over } \mathbf{2 6 0 0} \\
\text { (Purple colour - } \\
\text { Solid GRANITE) }\end{array}$ & - \\
\hline $19.50-21.00$ & $\begin{array}{c}\text { RQD:100\% } \\
\text { (Light greyish brown spotted dark } \\
\text { grey and pale grey spotted dark } \\
\text { grey) }\end{array}$ & $\begin{array}{c}\text { Over } \mathbf{2 6 0 0} \\
\text { (Purple colour - } \\
\text { Solid GRANITE) }\end{array}$ & 3.03 \\
\hline
\end{tabular}

Since the resistivity image covers large area, therefore, the resistivity value is taken in a big range. The resistivity value was analysed by referring to [25] and the borehole field test result. At the depth of $15.00-21.00 \mathrm{~m}$, the solid granite was identified with the RQD value ranging more than $91 \%$ (very good rock quality identified as fresh rock) and the range of resistivity value of more than $2600 \Omega \mathrm{m}$. The ground water level was found at two (2) different depth which is at the depth of $18.00 \mathrm{~m}(\mathrm{GWL}=13.45 \mathrm{~m})$ and $21.00 \mathrm{~m}(\mathrm{GWL}=3.03 \mathrm{~m})$. The ground water level became one of the main factor that can be used to differentiate the subsurface material found in this area. If the material have high resistivity value when the GWL is exists, it show that the material identified is solid granite but when the resistivity value is slightly lower than solid granite, it is identified as fractured granite. Most of the solid granite identified in this 
region are pale grey (white) spotted dark grey which is found at the depth of $15.00-18.00 \mathrm{~m}$ while the pale grey (white) spotted dark grey and one end light greyish brown solid granite was found at the depth of $18.00-19.50 \mathrm{~m}$. At the depth of $19.50-21.00 \mathrm{~m}$, the light greyish brown spotted dark grey and pale grey spotted dark grey solid granite was found.

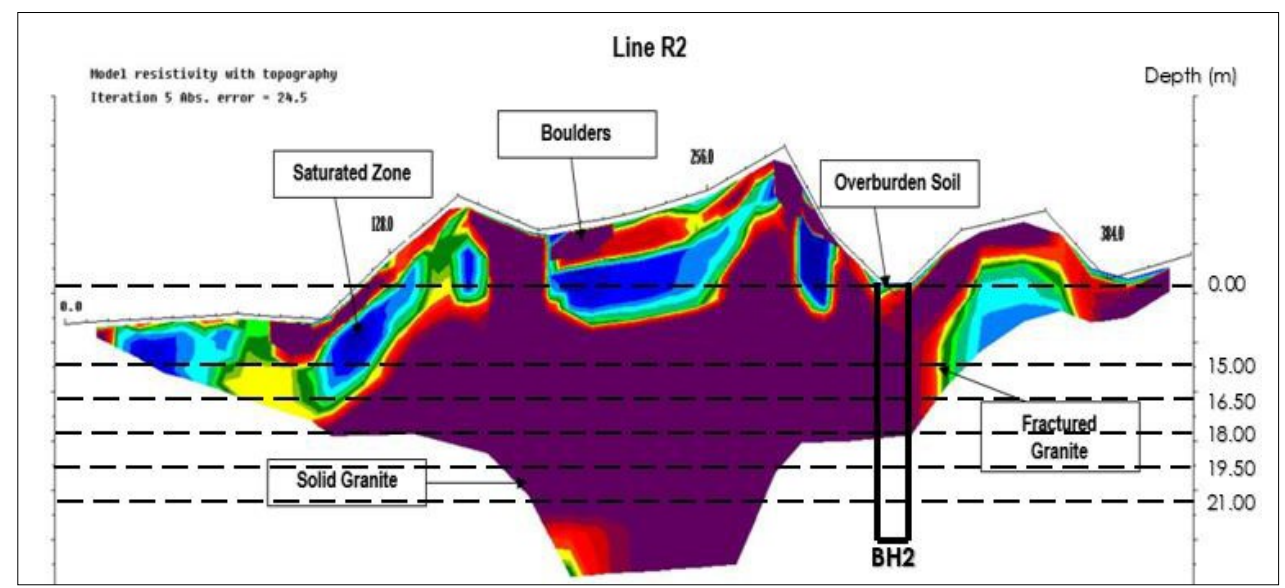

Fig. 14 - Borehole field test with resistivity imaging of BH2-R2

Table 15 shows the comparison of borehole field test result of BH3 and resistivity survey line 4 (R4) result conducted at the study site. Fig. 15 illustrates the borehole field test with resistivity imaging of BH3-R4. Based on the result tabulated in Table 15 and illustrated in Fig. 15, the results showed a good agreement between the borelog profiles and resistivity values. The subsurface with low resistivity value were interpreted as overburden soil (mainly silty sand) which was represented by dark blue to blue colour with the range of resistivity values of $100-1000 \Omega \mathrm{m}$ whereas, the high resistivity values were interpreted as solid granite which was represented by red to dark purple colour at the depth of $10 \mathrm{~m}$ from the surface with the range of resistivity value of more than $2000 \Omega \mathrm{m}$. The resistivity value which is a little bit lower than solid granite with the range of resistivity value of $1200-2000 \Omega \mathrm{m}$ is classified as fractured granite which was represented by light green to yellow colour.

Table 15 - Comparison of borehole field test result of BH3 and resistivity survey line R4 (BH3-R4)

\begin{tabular}{|c|c|c|c|}
\hline Depth (m) & Borehole Field Test Result & $\begin{array}{c}\text { Resistivity Value } \\
(\Omega \mathrm{m})\end{array}$ & $\begin{array}{c}\text { Ground Water } \\
\text { Level (m) }\end{array}$ \\
\hline $10.00-11.50$ & $\begin{array}{c}\text { RQD:93\% } \\
\text { (Pale grey (white) spotted dark } \\
\text { grey) }\end{array}$ & $\begin{array}{c}\text { Over } \mathbf{2 6 0 0} \\
\text { (Purple colour - } \\
\text { Solid GRANITE) }\end{array}$ & - \\
\hline $11.50-13.00$ & $\begin{array}{c}\text { RQD:100\% } \\
\text { (Light greyish brown pale } \\
\text { grey(white) spotted dark grey) }\end{array}$ & $\begin{array}{c}\text { Over } \mathbf{2 6 0 0} \\
\text { (Purple colour - } \\
\text { Solid GRANITE) }\end{array}$ & 9.50 \\
\hline $13.00-14.50$ & $\begin{array}{c}\text { RQD: } \mathbf{1 0 0 \%} \\
\text { (Light greyish brown pale } \\
\text { grey(white) spotted dark grey) }\end{array}$ & $\begin{array}{c}\text { Over } \mathbf{2 6 0 0} \\
\text { (Purple colour - } \\
\text { Solid GRANITE) }\end{array}$ & - \\
\hline $14.50-16.00$ & $\begin{array}{c}\text { RQD:100\% } \\
\text { (Light greyish brown spotted dark } \\
\text { grey and pale grey spotted dark } \\
\text { grey) }\end{array}$ & $\begin{array}{l}\text { Over } \mathbf{2 6 0 0} \\
\text { (Purple colour - } \\
\text { Solid GRANITE) }\end{array}$ & 6.30 \\
\hline
\end{tabular}

However, the resistivity image cannot differentiate the type of material either hard material or rock. Since the resistivity image covers large area, therefore, the resistivity value is taken in a big range. The resistivity value was analysed by referring to [25] and the borehole field test result. At the depth of $10.00-16.00 \mathrm{~m}$, the solid granite was identified with the RQD value ranging more than $91 \%$ (very good rock quality identified as fresh rock) and the range of resistivity value of more than $2600 \Omega \mathrm{m}$. The ground water level was found at two (2) different depth which is at the depth of $13.00 \mathrm{~m}(\mathrm{GWL}=9.50 \mathrm{~m})$ and $16.00 \mathrm{~m}(\mathrm{GWL}=6.30 \mathrm{~m})$. The ground water level became one of the main factor that can be used to differentiate the subsurface material found in this area. If the material have high resistivity value when the GWL is exists, it show that the material identified is solid granite but when the resistivity value is slightly lower than solid granite, it is identified as fractured granite. Most of the solid granite identified in this region 
are light greyish brown pale grey (white) spotted dark grey which is found at the depth of $11.50-16.00 \mathrm{~m}$ while the pale grey (white) spotted dark grey solid granite was found at the depth of $10.00-11.50 \mathrm{~m}$.

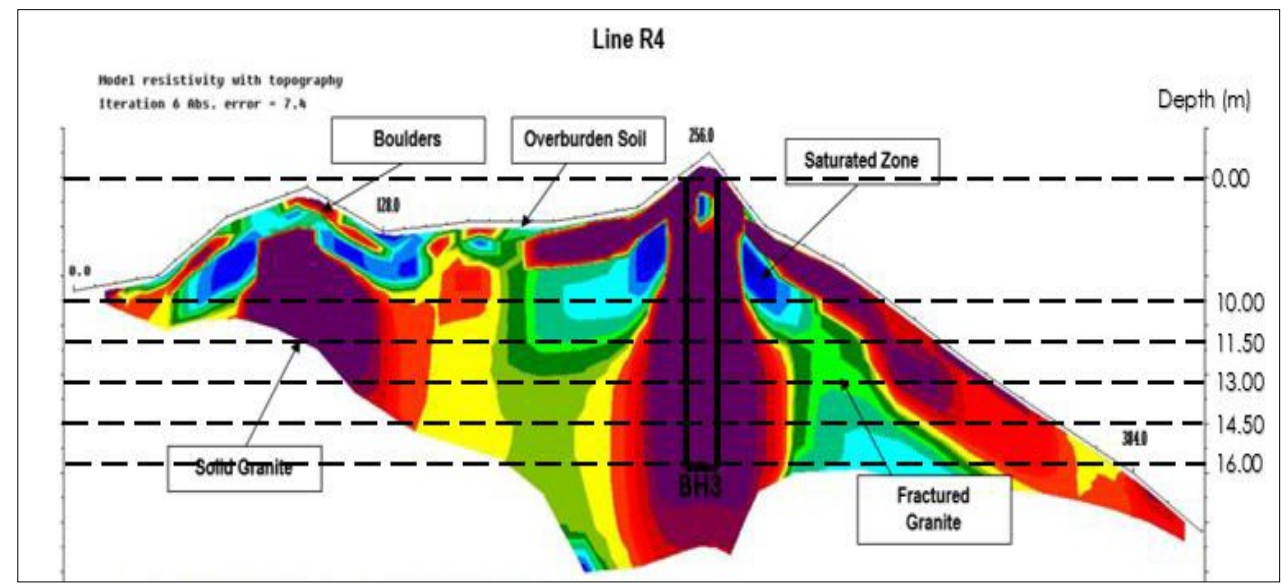

Fig. 15 - Borehole field test with resistivity imaging of BH3-R4

Table 16 shows the comparison of borehole field test result of BH4 and resistivity survey line 3 (R3) result conducted at the study site. Fig. 16 illustrates the borehole field test with resistivity imaging of BH4-R3. Based on the result tabulated in Table 16 and illustrated in Fig. 16, the results showed a good agreement between the borelog profiles and resistivity values. The subsurface with low resistivity value were interpreted as overburden soil (mainly silty sand) which was represented by dark blue to blue colour with the range of resistivity values of $100-1000 \Omega \mathrm{m}$ whereas, the high resistivity values were interpreted as solid granite which was represented by red to dark purple colour at the depth of $10 \mathrm{~m}$ from the surface with the range of resistivity value of more than $2000 \Omega \mathrm{m}$.

Table 16 - Comparison of borehole field test result of BH4 and resistivity survey line R3 (BH4-R3)

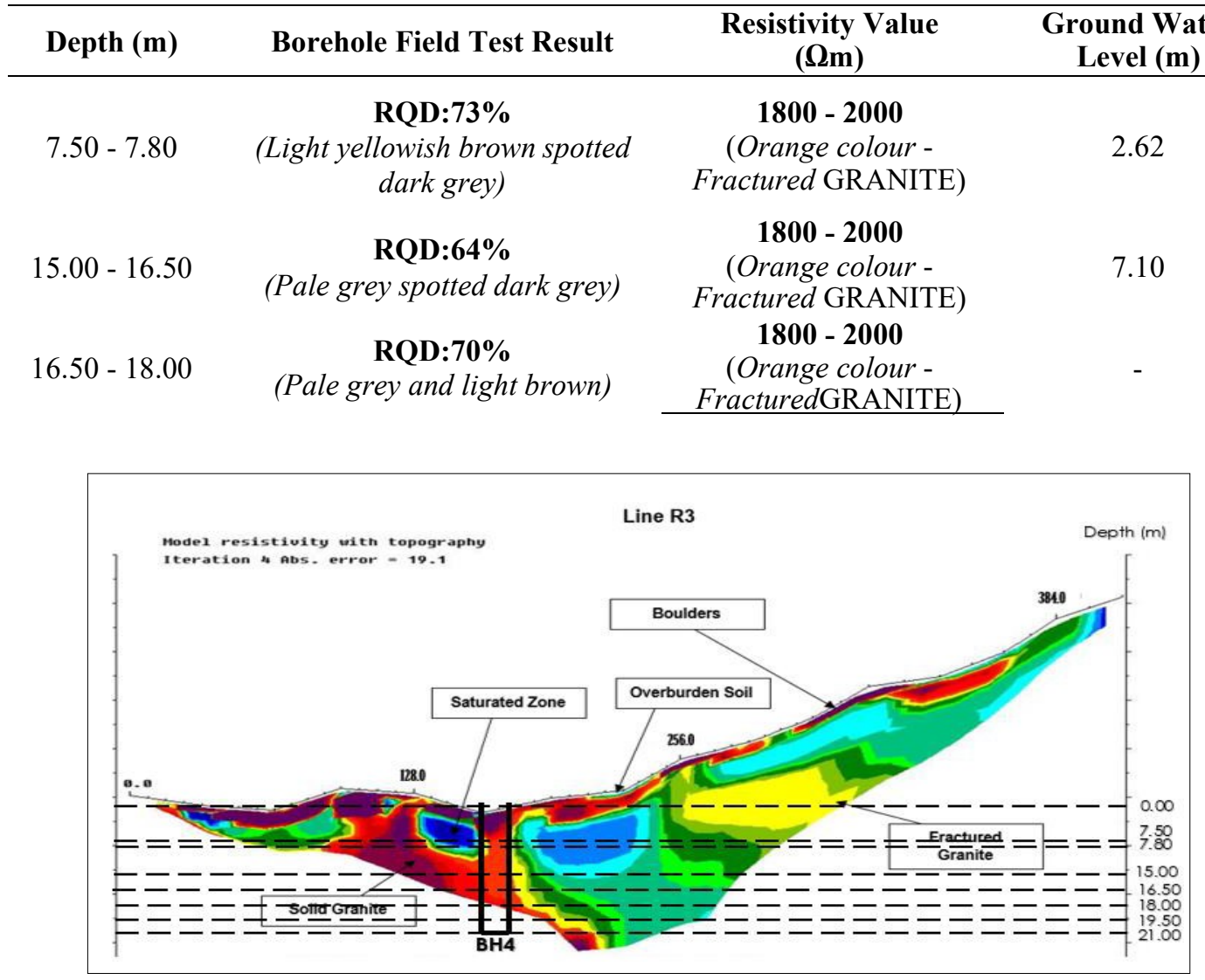

Fig. 16 - Borehole field test with resistivity imaging of BH4-R3 
The resistivity value which is a little bit lower than solid granite with the range of resistivity value of $1200-2000$ $\Omega \mathrm{m}$ is classified as fractured granite which was represented by light green to yellow colour. However, the resistivity image cannot differentiate the type of material either hard material or rock. Since the resistivity image covers large area, therefore, the resistivity value is taken in a big range. The resistivity value was analysed by referring to [25] and the borehole field test result. At the depth of $7.50-18.00 \mathrm{~m}$, the fractured granite was identified with the RQD value ranging from $64 \%$ - 73\% (fair rock quality identified as moderate weather rock) and the range of resistivity value of $1800-2000 \Omega \mathrm{m}$. The ground water level was found at two (2) different depth which is at the depth of $7.80 \mathrm{~m}(\mathrm{GWL}=$ $2.62 \mathrm{~m})$ and $15.00 \mathrm{~m}(\mathrm{GWL}=7.10 \mathrm{~m})$. The ground water level became one of the main factor that can be used to differentiate the subsurface material found in this area. If the material have high resistivity value when the GWL is exists, it show that the material identified is solid granite but when the resistivity value is slightly lower than solid granite, it is identified as fractured granite. Most of the fractured granite identified in this region are pale grey (white) spotted dark grey which is found at the depth of $15.00-18.00 \mathrm{~m}$ while the light yellowish brown spotted dark grey fractured granite was found at the depth of $7.50-7.80 \mathrm{~m}$.

Table 17 shows the comparison of borehole field test result of BH6 and resistivity survey line 5 (R5) result conducted at the study site. Fig. 17 illustrates the borehole field test with resistivity imaging of BH6-R5. Based on the result tabulated in Table 17 and illustrated in Fig. 17, the results showed a good agreement between the borelog profiles and resistivity values. The subsurface with low resistivity value were interpreted as overburden soil (mainly silty sand) which was represented by dark blue to blue colour with the range of resistivity values of $100-1000 \Omega \mathrm{m}$ whereas, the high resistivity values were interpreted as solid granite which was represented by red to dark purple colour at the depth of $10 \mathrm{~m}$ from the surface with the range of resistivity value of more than $2000 \Omega \mathrm{m}$. The resistivity value which is a little bit lower than solid granite with the range of resistivity value of $1200-2000 \Omega \mathrm{m}$ is classified as fractured granite which was represented by light green to yellow colour.

Table 17 - Comparison of borehole field test result of BH6 and resistivity survey line R5 (BH6-R5)

\begin{tabular}{|c|c|c|c|}
\hline Depth (m) & Borehole Field Test Result & $\begin{array}{c}\text { Resistivity Value } \\
(\Omega \mathrm{m})\end{array}$ & $\begin{array}{c}\text { Ground Water } \\
\text { Level (m) }\end{array}$ \\
\hline $2.60-4.10$ & $\begin{array}{c}\text { RQD:80\% } \\
\text { (Pale grey spotted dark grey) }\end{array}$ & $\begin{array}{c}\mathbf{1 9 0 0}-\mathbf{2 6 0 0} \\
\text { (Red colour - Solid } \\
\text { GRANITE) }\end{array}$ & 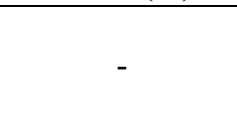 \\
\hline $4.10-5.60$ & $\begin{array}{c}\text { RQD:90\% } \\
\text { (Pale grey spotted dark grey) }\end{array}$ & $\begin{array}{c}\mathbf{1 9 0 0}-\mathbf{2 6 0 0} \\
\text { (Red colour - Solid } \\
\text { GRANITE) }\end{array}$ & 4.05 \\
\hline $5.60-7.10$ & $\begin{array}{c}\text { RQD:76\% } \\
\text { (Pale grey spotted dark grey and } \\
\text { light brown) }\end{array}$ & $\begin{array}{c}\mathbf{1 9 0 0}-\mathbf{2 6 0 0} \\
\text { (Red colour - Solid } \\
\text { GRANITE) }\end{array}$ & - \\
\hline $7.10-8.60$ & $\begin{array}{c}\text { RQD:85\% } \\
\text { (Pale grey spotted dark grey and } \\
\text { light brown) }\end{array}$ & $\begin{array}{c}\mathbf{1 9 0 0}-\mathbf{2 6 0 0} \\
\text { (Red colour - Solid } \\
\text { GRANITE) }\end{array}$ & 3.16 \\
\hline
\end{tabular}

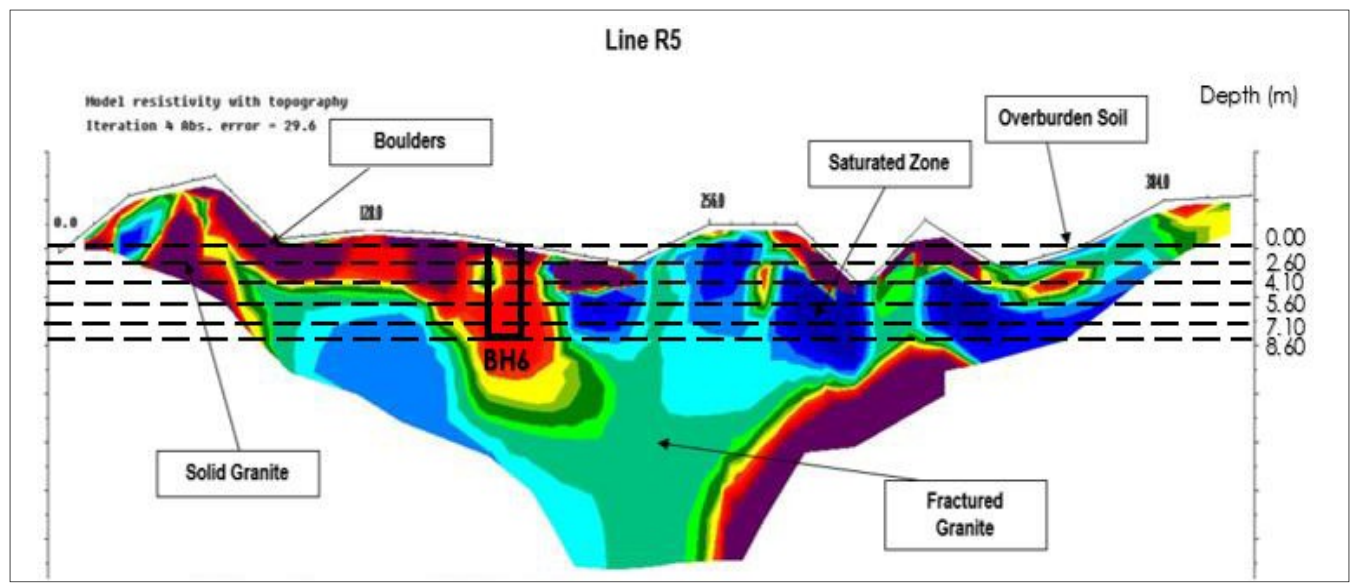

Fig. 17 - Borehole field test with resistivity imaging of BH6-R5

However, the resistivity image cannot differentiate the type of material either hard material or rock. Since the resistivity image covers large area, therefore, the resistivity value is taken in a big range. The resistivity value was analysed by referring to [25] and the borehole field test result. At the depth of $2.60-8.60 \mathrm{~m}$, the solid granite was identified with the RQD value ranging from $76 \%$ - 90\% (good rock quality identified as hard rock) and the range of 
resistivity value of $1900-2600 \Omega \mathrm{m}$. The ground water level was found at two (2) different depth which is at the depth of $5.60 \mathrm{~m}(\mathrm{GWL}=4.05 \mathrm{~m})$ and $8.60 \mathrm{~m}(\mathrm{GWL}=3.15 \mathrm{~m})$. The ground water level became one of the main factor that can be used to differentiate the subsurface material found in this area. If the material have high resistivity value when the GWL is exists, it show that the material identified is solid granite but when the resistivity value is slightly lower than solid granite, it is identified as fractured granite. Most of the solid granite identified in this region are pale grey spotted dark grey which is found at the depth of $2.60-5.60 \mathrm{~m}$ and the pale grey spotted dark grey and light brown solid granite which was found at the depth of $5.60-8.60 \mathrm{~m}$.

Coherently, the results showed a good agreement between the borelog profiles and resistivity values. The subsurface with low resistivity value were interpreted as overburden soil (mainly silty sand) whereas, the high resistivity values were interpreted as solid granite. Moreover, the results obtained in this research proved that in site investigation purposes, the electrical resistivity can be useful tool in the assumption of the soil formation between the boreholes with a fair degree of accuracy.

\section{Conclusion}

A total of seven (7) electrical resistivity imaging profiles were collected in this geophysical survey. In general the acquired ERT lines are of good quality in relatively to the cloudy and sunny condition at the site during the acquisitions proceed. The processed data has enabled confident interpretation of the sub-surface condition. The geophysical study conducted by using resistivity imaging survey appear to have been successful in locating 3 distinctive geological units, which are the 1) overburden soil, 2) fractured granite, and 3) solid granite. In general, the survey area consists of granite bedrocks (Solid granitic bodies and fractured/jointed granites) overlain by overburden soil on top. There are 2 types of granitic bedrock that are identified from the ERI survey, the solid granite (Grade I) bodies which shows high resistivity (More than $2000 \Omega \mathrm{m}$ ), while the fractured or jointed granites (Grade III - V) are found to be lower in resistivity (20 to $2000 \Omega \mathrm{m}$ ). Solid granite is a type of rock that do not break easily by geological hammer and has no visible signs of decomposition while the fractured or jointed granites is a type of rock that can be broken by hand into smaller pieces and completely discoloured compared to solid granite. The resistivity image and boreholes field test result give almost similarity in result. However, the result shows some irregularities owing to several factors such as ground water level and soil grains. When the GWL is high and the soil is in coarse grained, the resistivity value will be lower and vice versa. The resistivity image has to compliment with borehole data to differentiate the subsurface material found. In this study, it was clearly seen that the ERI verified by the boreholes of the soil samples can be very a useful tools for the granite rock exploration. The inversion of the resistivity data obtained from RES2DINV software yielded useful information (resistivity value) that can become the potential location of the granite rock that can be explored without using borehole drillings. A dependable results was obtained throughout this study from geotechnical and ERI methods. The combination of these methods could be used as guidelines to the researchers and related authority for the investigation of similar granite rock exploration. ERI method is a non-destructive mapping method that does not disturb the structure and the function of the soil. The generated sections, maps and 3D models of the subsurface have provided relevant information which is able to guide point selection for geotechnical investigations, especially where the budget is limited and every part of the field could not be covered at very close grid. Geotechnical sampling along carefully selected points and along different delineated varying georesistivity zones, would provide relevant information that would account for heterogeneity of the subsurface.

\section{Acknowledgement}

The authors would like to thanks University Malaysia Pahang owing to the provided funding (UIC190803) throughout this project.

\section{References}

[1] Herman, R. (2001). An introduction to electrical resistivity in geophysics. American Journal of Physics, 69, $943-$ 953.

[2] Aizebeokhai, A. P. (2011). 2D and 3D geoelectrical resistivity imaging: Theory and field design. Scientific Research and Essays. 13, 459-470.

[3] Pánek, T., Hradecký, J. \& Šilhán, K. (2008). Application of Electrical Resistivity Tomography (ERT) in The Study of Various Types of Slope Deformations in Anisotropic Bedrock: Case studies from The Flysch Carpathians. Reston: American Society of Civil Engineers.

[4] Sk, M., Ramanujam, N., Champoil, V., Biswas, S. K., Rasool, Q. A. \& Ojha, C. (2018) Identification of groundwater in hard rock terrain using $2 \mathrm{D}$ electrical resistivity tomography imaging technique: Securing water scarcity at the time of seasonal rainfall failure, South Andaman. International Journal of Geosciences, 9, 59-70.

[5] Hazreek, Z. A. M., Rosli, S., Chitral, W. D., Fauziah, A., Azhar, A. T. S., Aziman, M. \& Ismail, B. (2015). Soil identification using field electrical resistivity method. In Journal of Physics: Conference Series, 622, 012030. 
[6] Khatri, R., Shrivastava, V. K. \& Chandak, R. (2011). Correlation between vertical electric sounding and conventional methods of geotechnical site investigation International Journal of Advanced Engineering Sciences and Technologies, 4, 42-53.

[7] Liu, C. \& Evett, J. B. (2008). Soils and Foundation. New Jersey: Pearson International.

[8] Godio, A., Strobbia, C. \& De Bacco, G. (2005) Geophysical characterisation of a rockslide in an alpine region. Engineering Geology, 83, 273-286.

[9] Cosenza, P., Marmet, E., Rejiba, F., Jun Cui, Y., Tabbagh, A. \& Charlery, Y. (2006). Correlations between geotechnical and electrical data: A case study at Garchy in France. Journal of Applied Geophysics, 60, 165-178.

[10] Hazreek, Z. A. M., Rosli, S., Chitral, D. C., Fauziah, A., Azhar, A. T. S., Aziman, M. \& Ismail, B. (2015). Soil identification using field electrical resistivity method. Journal of Physics: Conference Series, 622, 1-7.

[11] Khatri, K., Shrivastava, V. K., \& Chandak, R. (2011). Correlation between vertical electric sounding and conventional methods of geotechnical site investigation. International Journal Advanced Engineering Sciences and Technologies, 4, 042-053.

[12] Osinowo, O. O. \& Falufosi, M. O. (2018). 3D electrical resistivity imaging (ERI) for subsurface evaluation in preengineering construction site investigation. NRIAG Journal of Astronomy and Geophysics, 7, 309-317.

[13] Almalki, H., El-Werr, A.K. \& Abdel-Rahman, K. (2011). Estimation of near-surafce geotechnical parameters using seismic measurements at the proposed KACST expansion site, Riyadh, KSA. Arabian Journal of Geosciences, 4, 1131-1150.

[14] Sudha, K., Israil, M., Mittal, S. \& Rai, J. (2009). Soil characterization using electrical resistivity tomography and geotechnical investigations. Journal of Applied Geophysics, 67, 74-79.

[15] Oh, S. \& Sun, C. G. (2008). Combined analysis of electrical resistivity and geotechnical SPT blow counts for the safety assessment of fill dam. Environmental Geology, 54, 31-42.

[16] Hack, R. (2000). Geophysics for Slope Stability. Surveys in Geophysics, 21, 423-448.

[17] Mauritsch, H. J., Seiberl, W., Arndt, R., Romer, A., Schneiderbauer, K. \& Sendlhofer, G. P. (2000). Geophysical investigations of large landslides in the Carnic Region of Southern Austria, Engineering Geology, 56, 373-388.

[18] Herman, R. (2001). An introduction to electrical resistivity in geophysics. American Journal of Physics, $69,943$.

[19] Ismail, N. I. \& Yaacob, W. Z. W. (2018). Application of electrical resistivity tomography (ERT) for slope failure investigation: A case study from Kuala Lumpur. Jurnal Teknologi, 80, 116-124.

[20] Ghani, A. (2019). Geochemical characteristics of S- and I-Type Granites: Example from Peninsular Malaysia granites. Bulletin of the Geological Society of Malaysia, 51, 123-134.

[21] Metcalfe, I. (2013). Tectonic evolution of the Malay Peninsula. Journal of Asian Earth Sciences, 76, $195-213$.

[22] Keller, G. V. \& Frischknecht, F. C. (1966). Electrical methods in geophysical prospecting. New York: Pergamon Press.

[23] Dey, A. \& Morrison, H. F. (1979). Resistivity modelling for arbitrarily shaped two-dimensional structures. Geophysical Prospecting, 27, 106-136.

[24] Loke, M. H. \& Barker, R. D. (1996). Rapid least squares inversion of apparent resistivity pseudosection using a quasi-newton method. Geophysical Prospecting, 44, 131-152.

[25] Loke, M. H. (1999). A practical guide to 2D and 3D surveys. Electrical Imaging Surveys for Environmental and Engineering Studies, 1, 8-10.

[26] Deere, D. U. (1963). Technical description of rock cores for engineering purposes. Vienna: Springer 